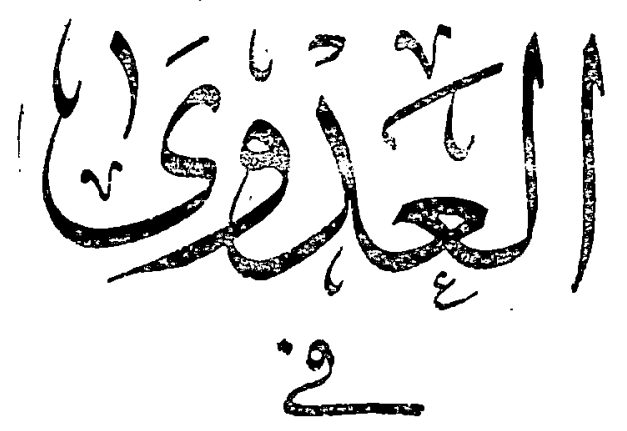

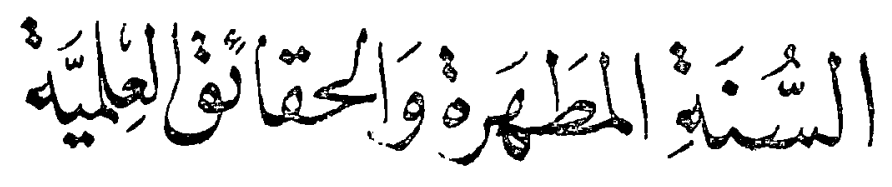

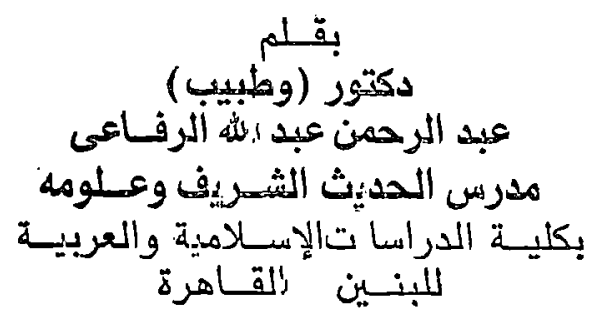





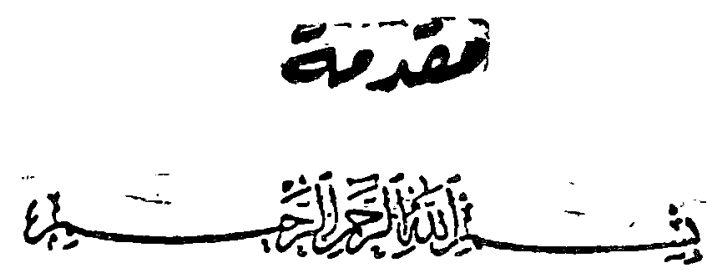

الحمد لله خلق اللاندسان من علق ، وأخسرجه من بطن أمه لا يعلمه

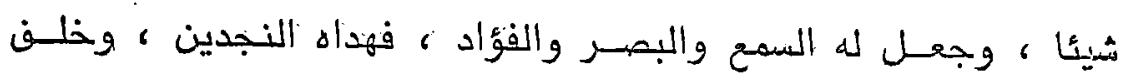

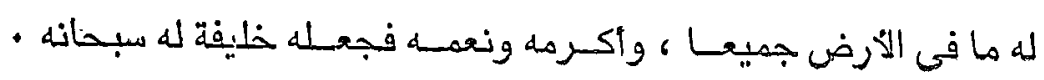
اللهم هـل وسلم على سيدنا محمـد النبى الأمى وآلـه وصحبـه

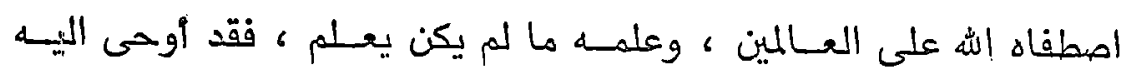
الكتاب والحكمة ، فيهما من أسسرار الكون المــرئى والخفى ما لا يدركه

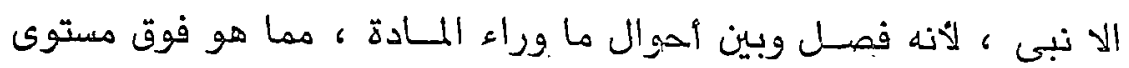
الججوارح الانسـانية ، والتصورات العقليـة ، والخطرات النفسية ، لأنه من لدن حكيم عليم ، الذى خلق الأكوان على عينـه ، ووضهـح قوانينها وقدرها ، فهى قائمة به 6 محفوظة بارادته ومشيئه .

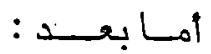

فهذا بحث عملى في ( العـدوى ) ) ما هى ؟ ومهـاذا ورد فيهـا

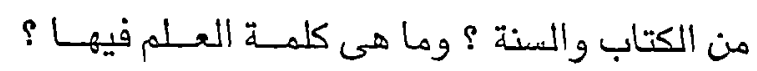
ووبحسن بنا أولا أن نعزف المدوى ، فى اللسان العربى •

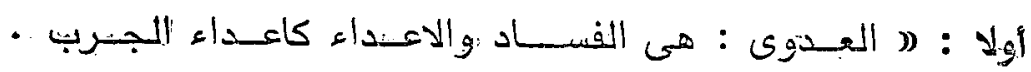

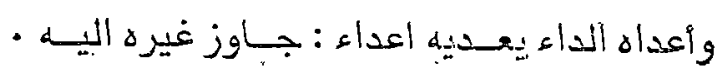

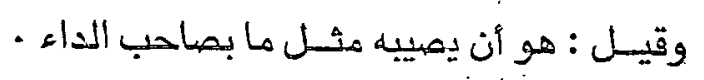

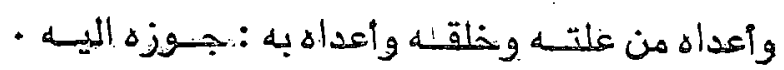

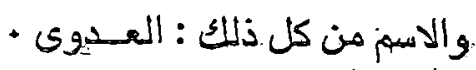

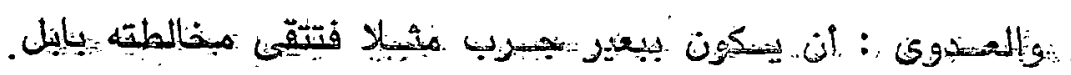

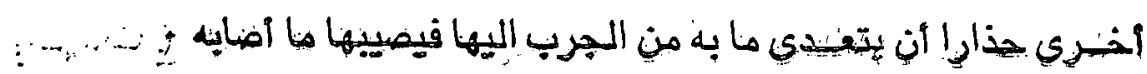




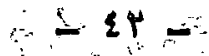

وقال الأزهـرى : العدوى أن يكون ببعير جـرب أو بانسـان جذام ،

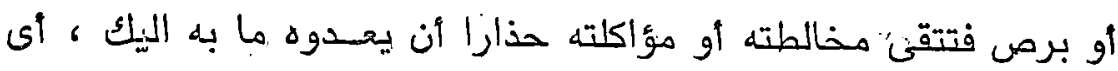

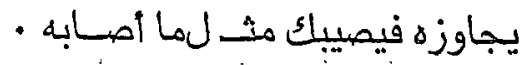
ويقبال : ان الجــرب ليعدى ، أى يجــاوز ذا الجـبرب الى من قاربه حتى يجـرب -

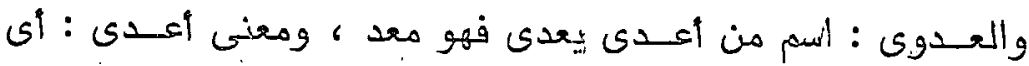

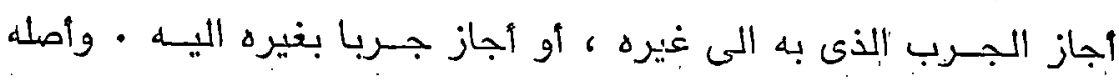

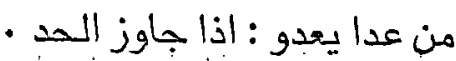
وتعـادى القوم : أى أصاب هــذا مثـل داء هـذذا ") -

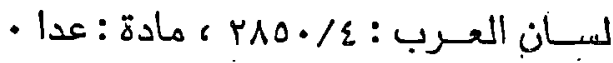
فالعـدوى اذن حقيقة لزــوية -

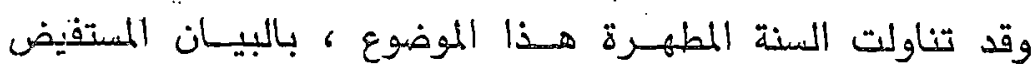
والتوضيح المفيد ، وأحاطت بـه من جميسع جوانبه ، بحيث لا يخرج عن

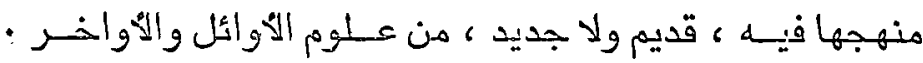
والنـاظر فنى الأحاديث المثنـريفة سوف يجد أن هناك طهائفة هن

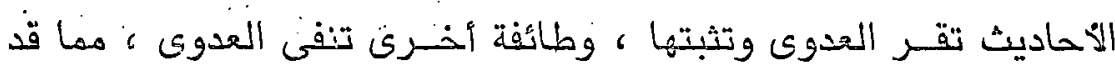
يوقع الباحث فى وهم التعـارض الحقتيقى بين اللأحاديث ، ولاسيما أن كلا الطائفتين من صحيح 'الحديث ه، بل قد تروى هـذه وتلك عن محابى واحد ، وفى مصنف صحيح واحد -

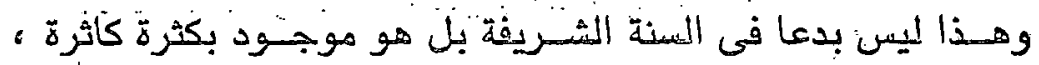

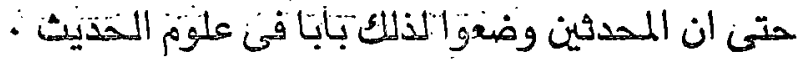

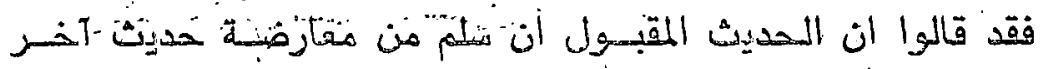

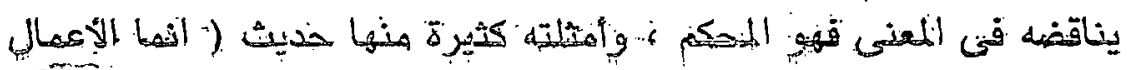

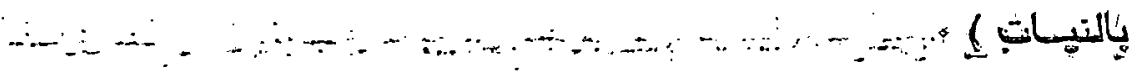


فان عورض الحديث بمثـله فاما أن يمكن الجمــع بينهما ، أولا ، فان أمكن الجمسع بينهما بدون تعسف فهو مختلف الحديث ، واختـلاف الحديث علهز جليـل كان الشافعى رحمــه الله تعبالى أول من الف فيــ

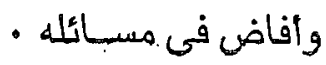

وتدخل أحاديث العدوى فى هذا النوع من اختلاف الحديث ، فان

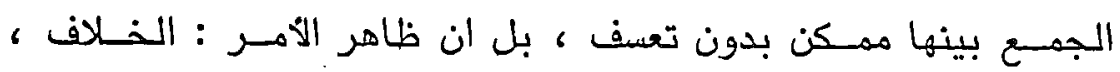
وحقيقته : الصواب والحكمة .

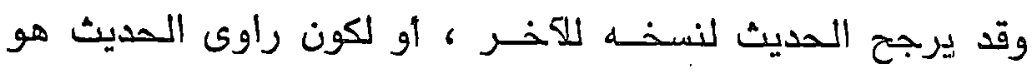
هاحب الواقعة التى ورد فيها الحديث ، أو قد يرجح الحديث للاحتياط ، وهي ، أو استصحابا للأصنـل

$$
\text { ولنبدأ بعـرض الآحاديث التى شثبت العدوى : }
$$

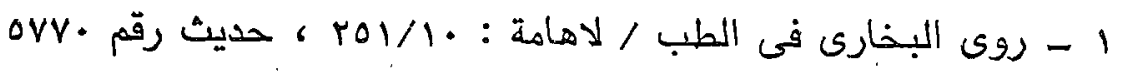

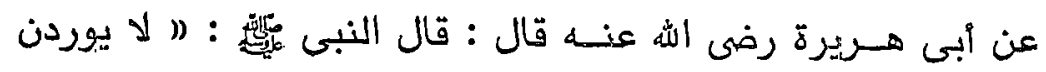

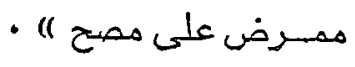

والمرض : هو الذى له ابل مرضى ، وهو السم فاعل من أمسرض

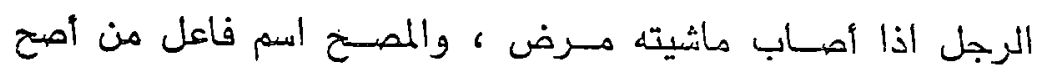

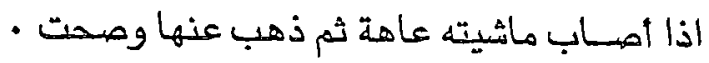

ثم رواله فى باب : لا عدوى ، حديث رقم OVVY بلفظ : (لا توردوا

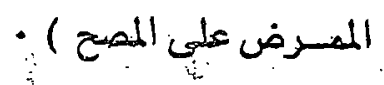

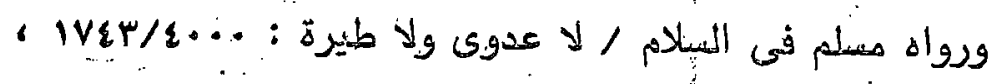

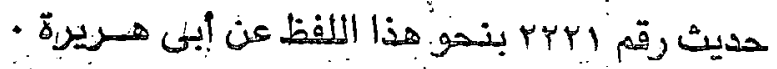

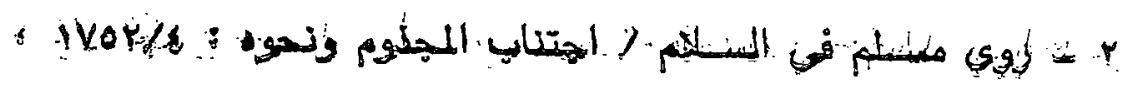




\section{$-2 \varepsilon-$}

حديث رقم اسبr عن عهـرو بن الشريد عن أبيه قال : كان في وفت

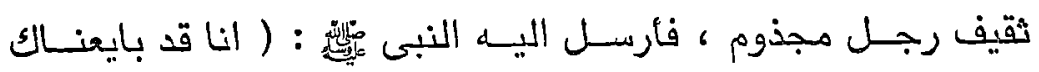
ن

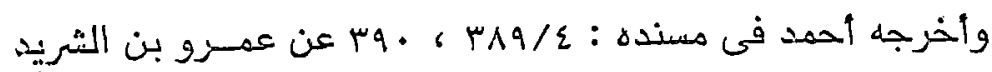

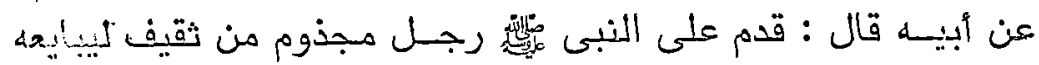

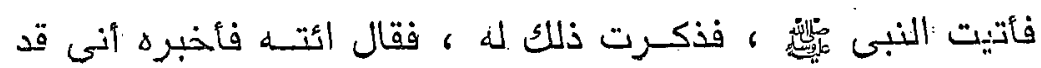

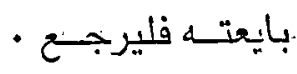

وكذا أخرجه ابن ماجه فيى اللطب / الجذام : IVY/T ، حديث

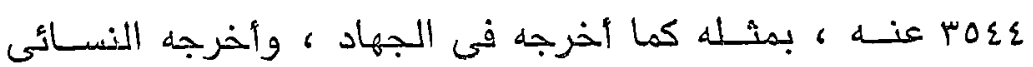

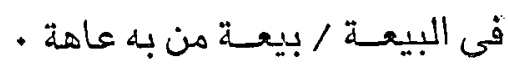

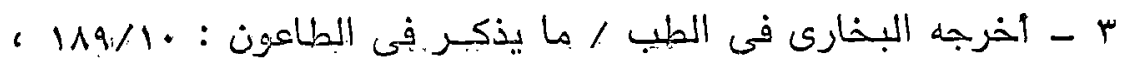
حديث رقم OVra عن عبد الله بن عبــاس ( أن عمسر بن الخطاب

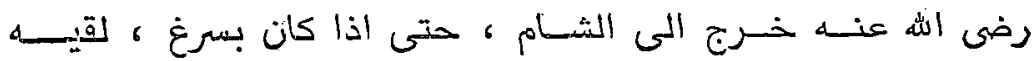

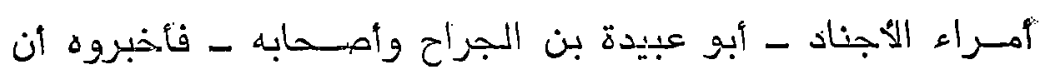
الموباء قد وقـع بأرض الثـام ، قال عبد اله بن عباس : فقال عمر :

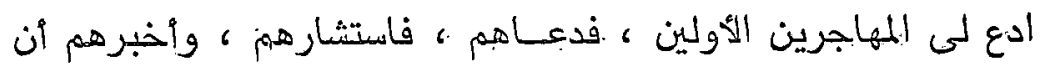
النوباء قد وقبـع فى الثـام ، فاختلفوا ، فقال بعضهم قد خرجنا

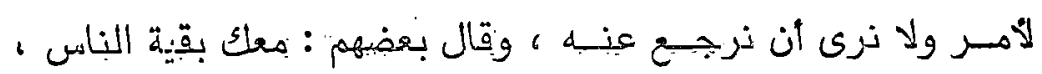

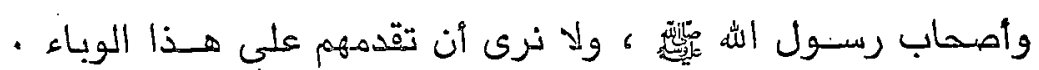

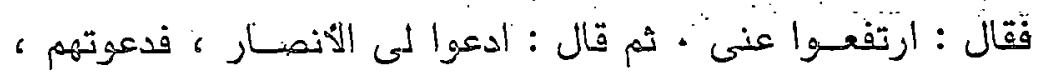

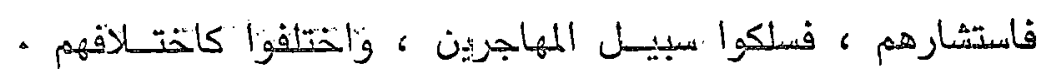

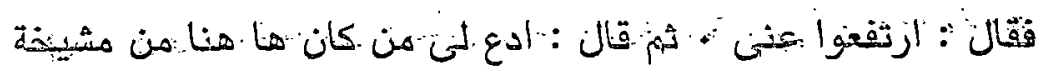

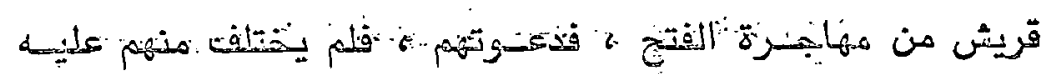

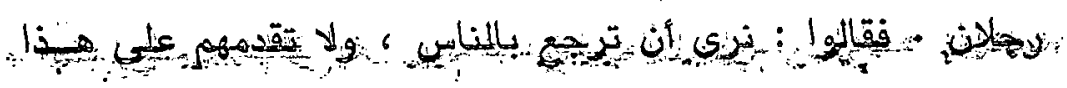


الوباء ، فنادى عمـر فى الناس : انى مصبح على ظهـر ، فأصبحوا

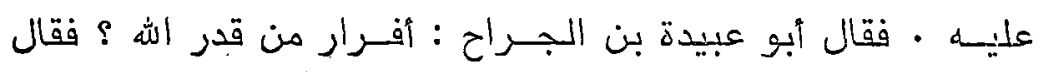

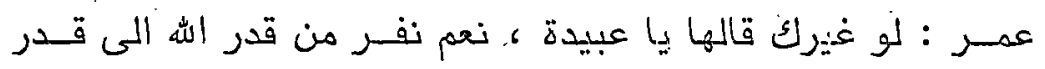

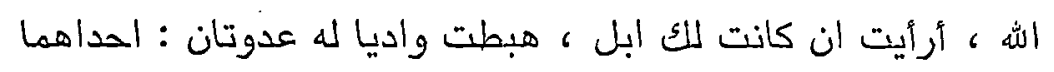

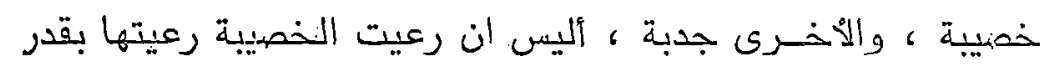

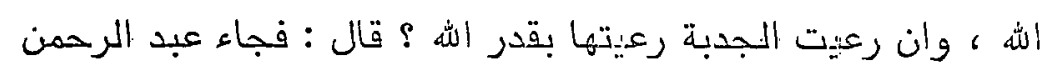

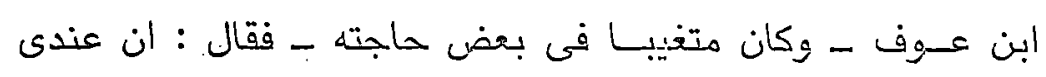

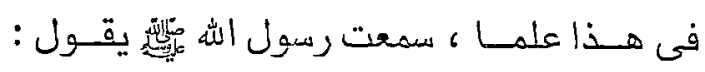

( اذا سمتتم به بأرض فالا تقدموا عليهه ، واذا وقـع بأرض وأنتم

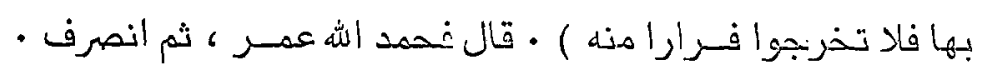

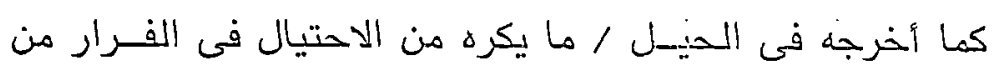

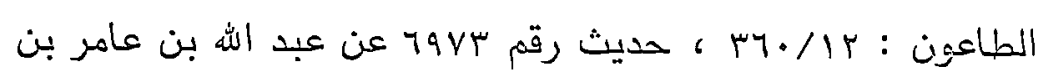

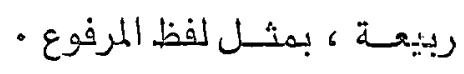

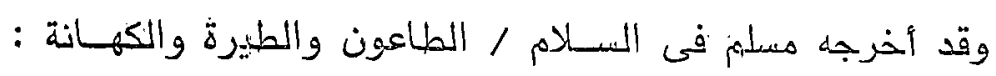

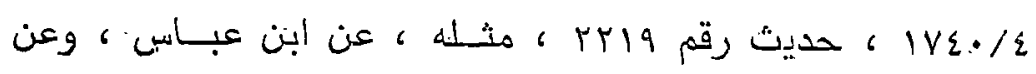

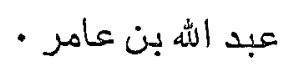

قال ابن حجـر فى تفسيره : ( سـرغ : مدينة بالثـام انتتجحها

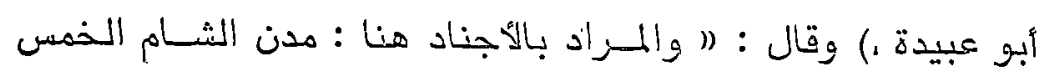

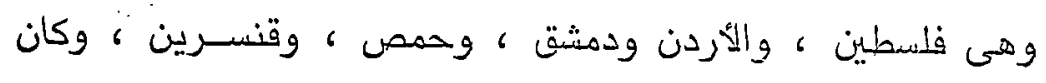

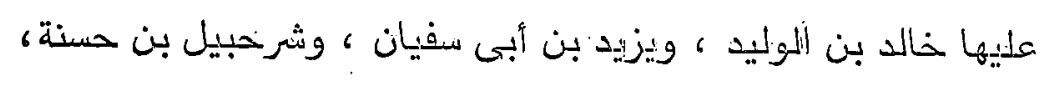

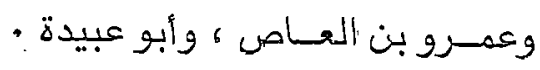

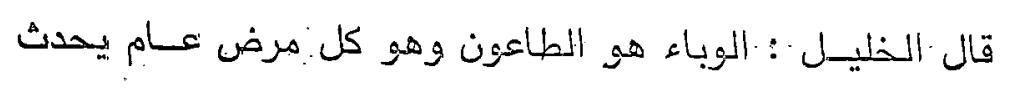

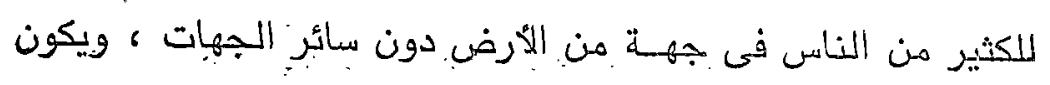

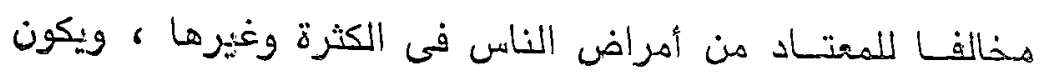


مرضهم نوبا وإحدا ، بخلاف سبائر الإوقات فان أمراضهم فيهـا

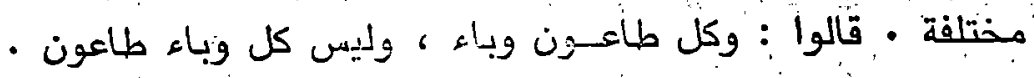

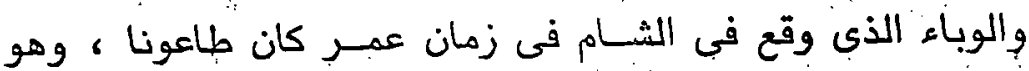

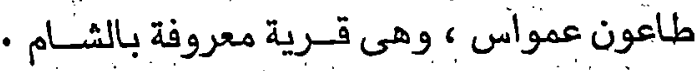

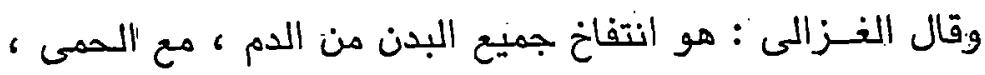

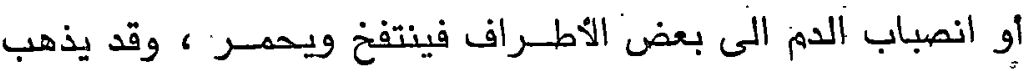

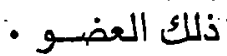

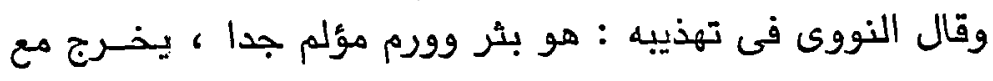

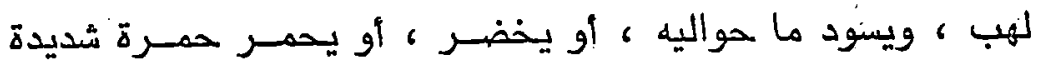

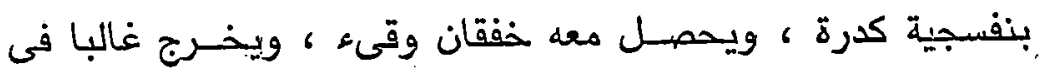

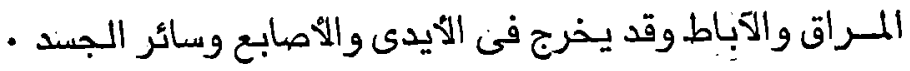

وقال جماعة من الآطباء منهم أبو على بن سينا : الطاعون مادة

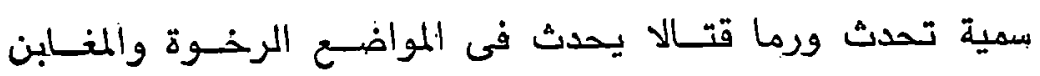

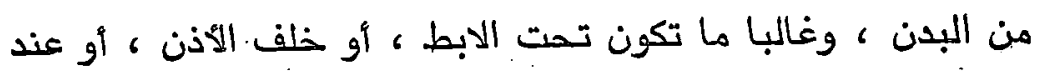

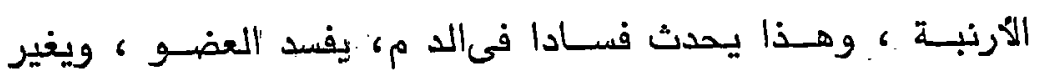

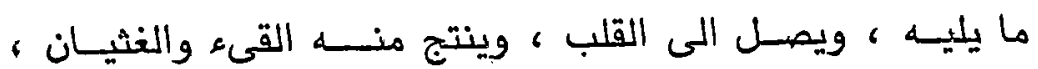

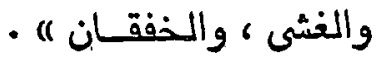

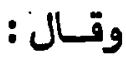

" ( قوله ( من مشيخة قـريش ) : ضبط ( مشيخة ) بفتح الميم

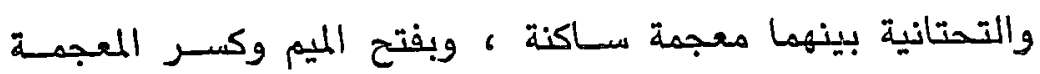

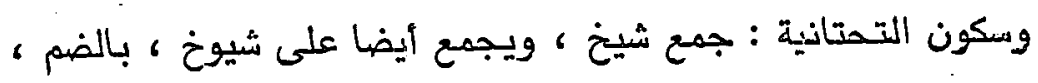

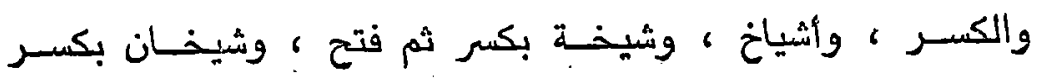
ثم سكون • 


\section{$-2+=$}

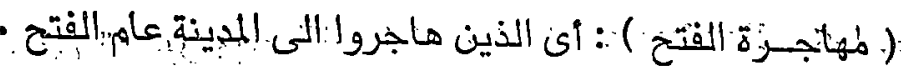

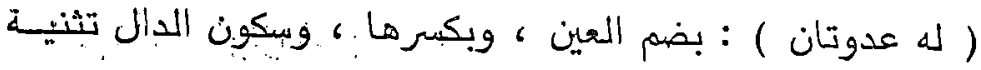

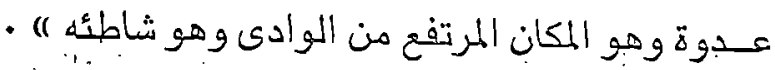

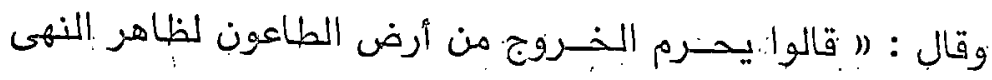

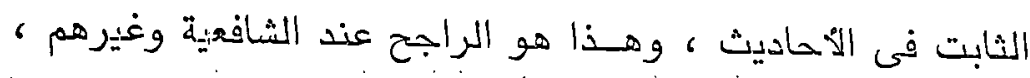

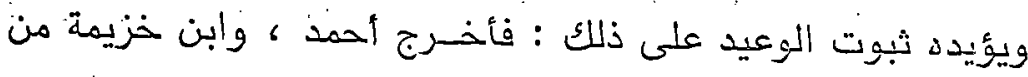

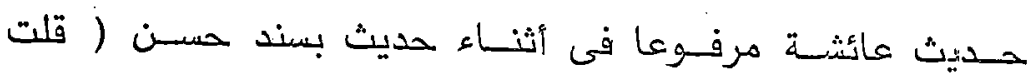

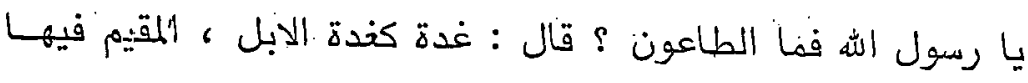

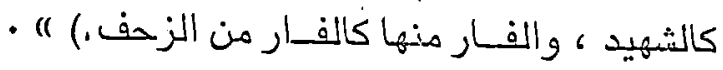
وقــال : (ا قال الغــزالى : الهــواء لا يضـــر من حيث ملاقاته

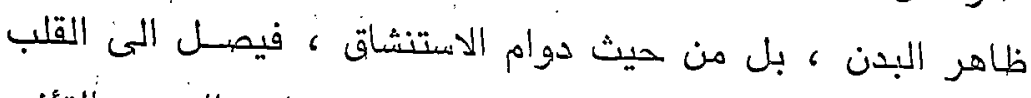

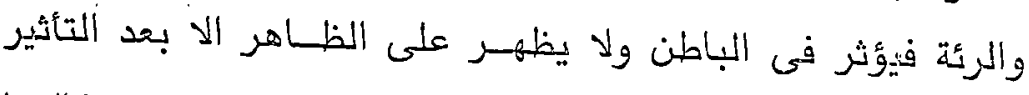

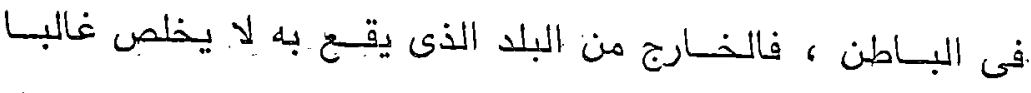

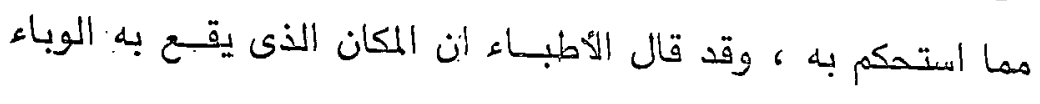

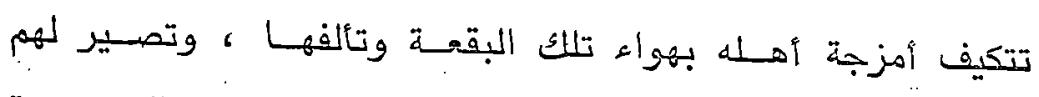

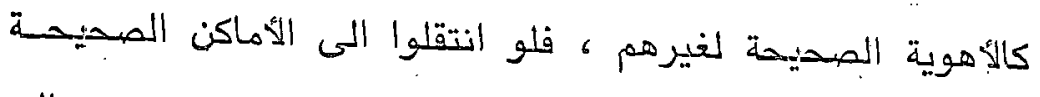

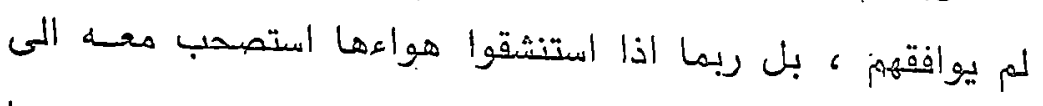

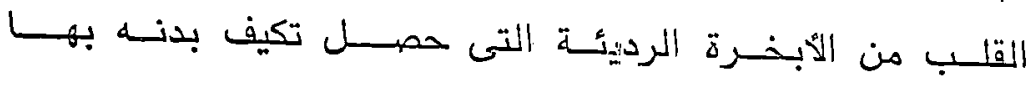
فأفســدته هـ انتهى ملنصـا من فتح البارى بتّهرف •

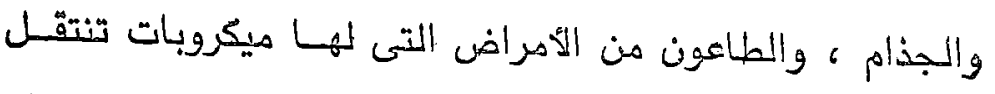

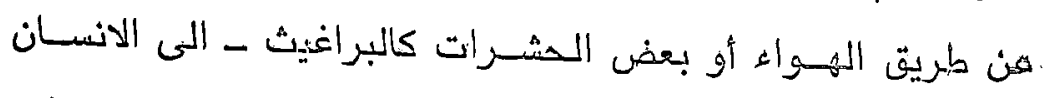

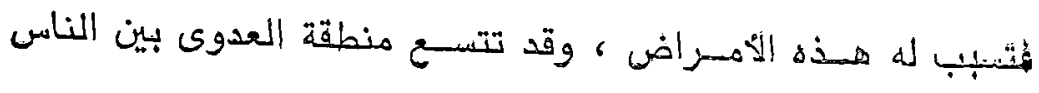




\section{$-\varepsilon k-$}

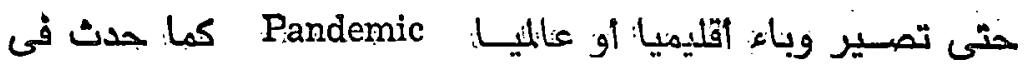

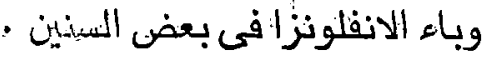

وقد أخـرج الامام مسلم فى الباب جمُلة من الأحاديث في هـــا المتنى ، منها حديث الطاعون السابق عن أسامة بن زيد ، بمثله ـ

ع - أخـرج أبو داود فى الطب / الطيرة والخط : ror/17 عن فروة

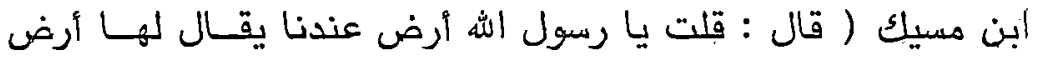

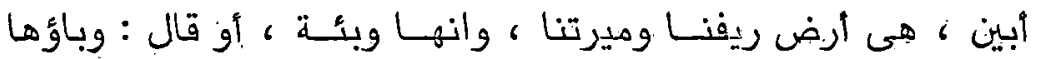

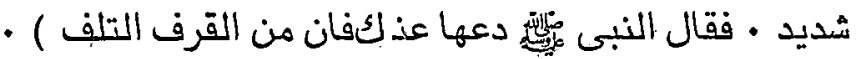
واسم الأرض هو هــذا ، وقوله : ريفنا أى زرعنـا ، وميرتنا :

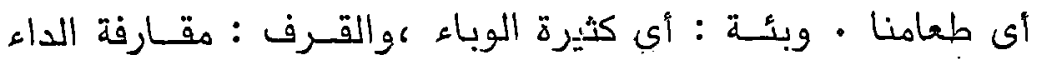

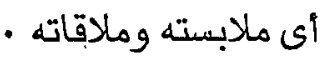

وهذا الحديث مما سكت عنه أبو داود ، فهو حسن ، وقد أخرجه

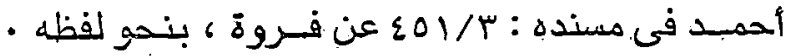

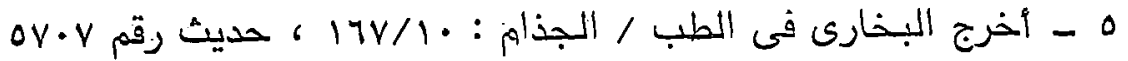

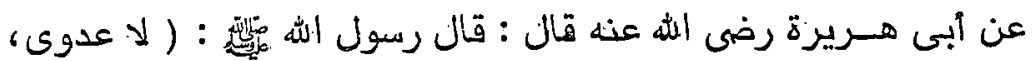

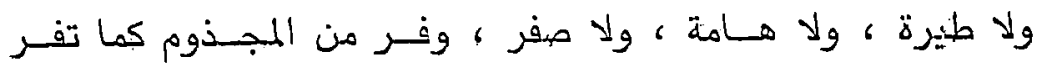

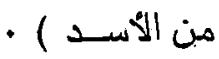

والطيرة : بكسر الطساء وفتح المثنـاة تحت وقد تسكن ، هى

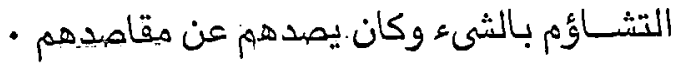

وروى أبو داود فى الطب / الطبيرة والخطب :

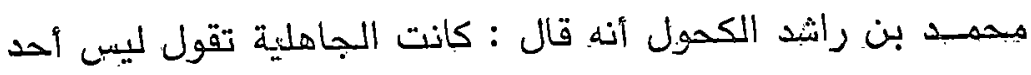

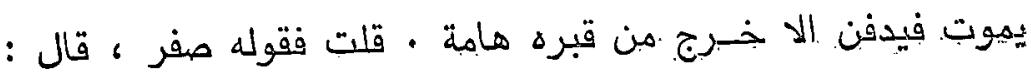

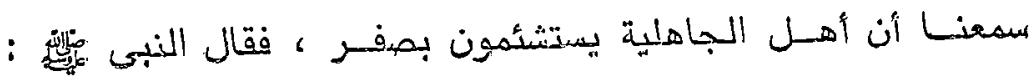




\section{$-89-$}

لا صفر ، قال محمدد : وقد سهنا من يقول هو وجسح يأخـذ فيى

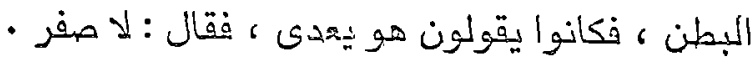

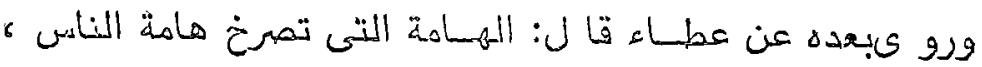
وليست بهامة الانسـان : انما هى دابة ( أى البومة وكانوا يتثائمون

وقد قال الحافظ بن حجبر في الفتح :

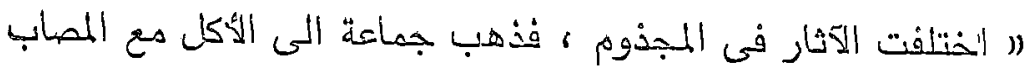

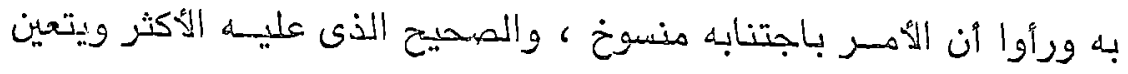

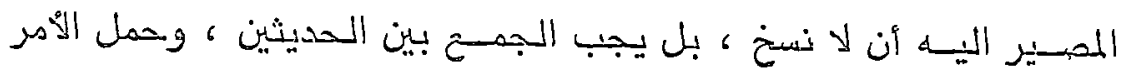

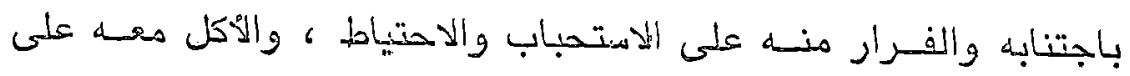

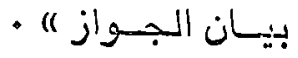

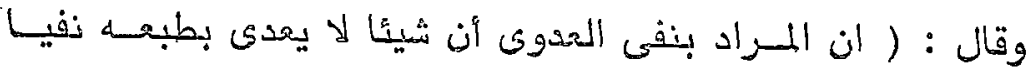

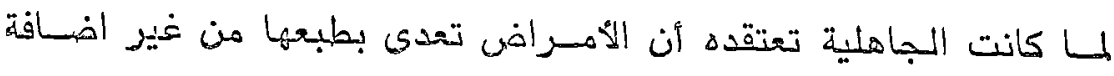

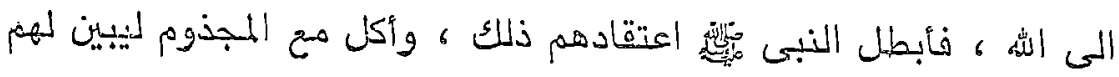

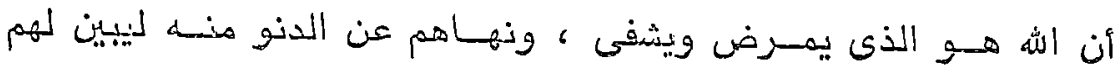

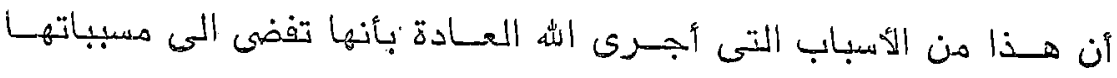

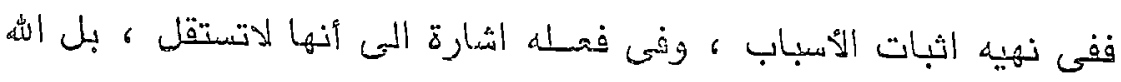

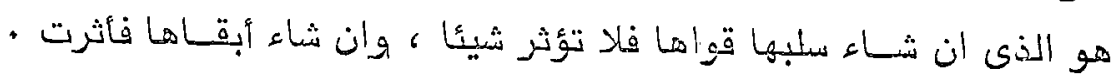

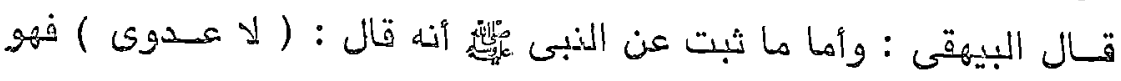

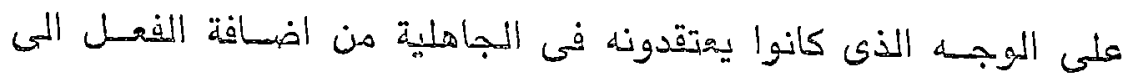

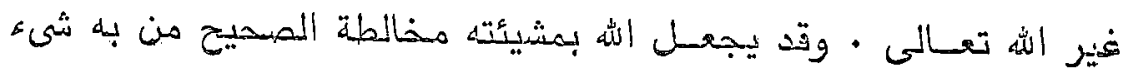

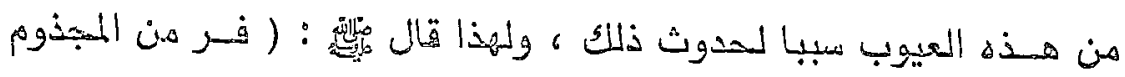

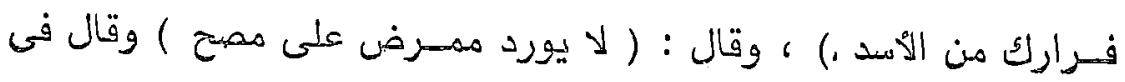

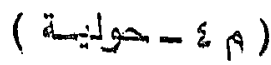




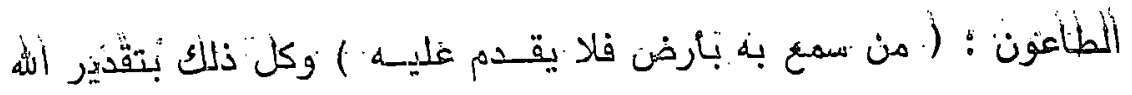

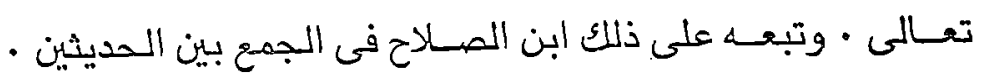

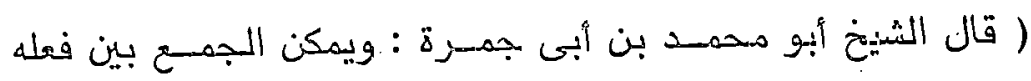

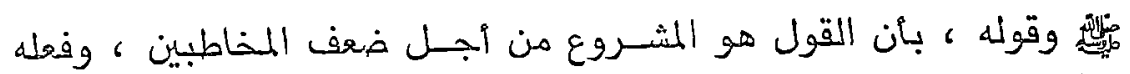

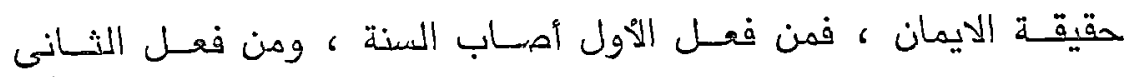

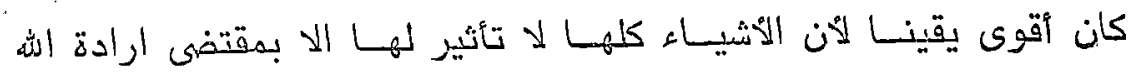

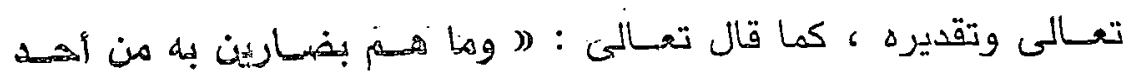

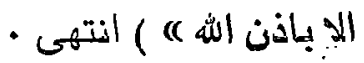

وهـذه المفـاهيم من أجسود ما حمل عليه معسانى هذه الأجماديث

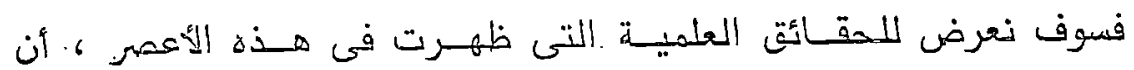

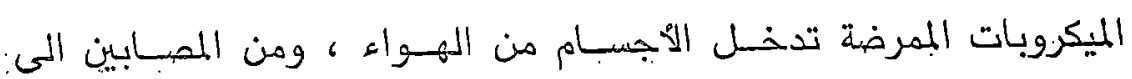

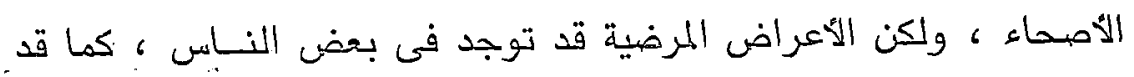

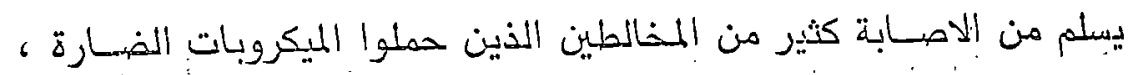

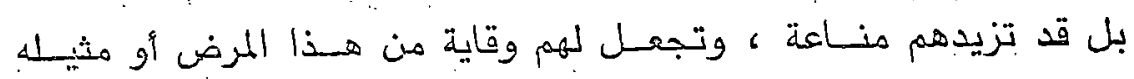

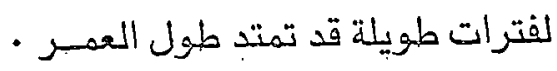

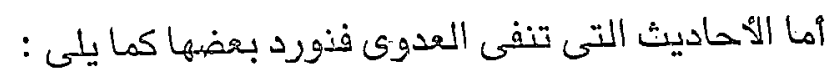

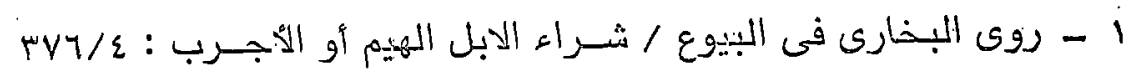

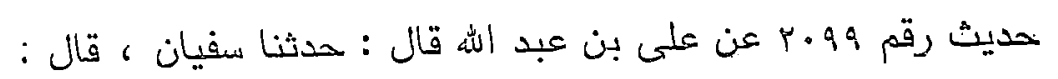

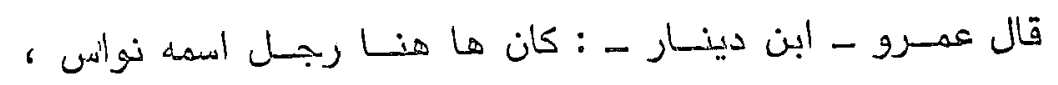

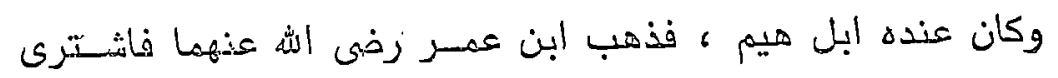

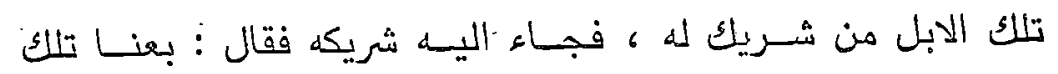

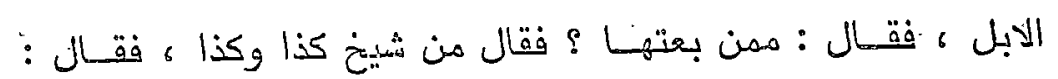

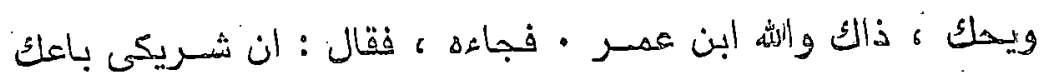

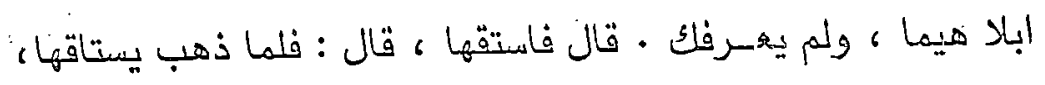

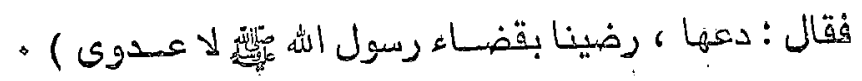




$$
\therefore \text { Oी }
$$

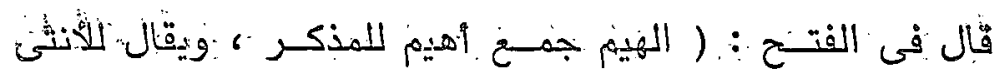

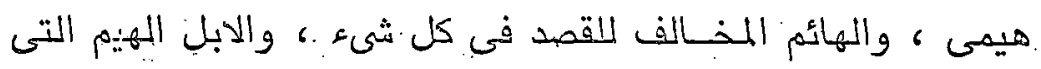

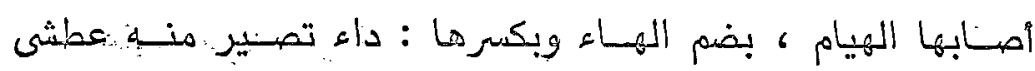

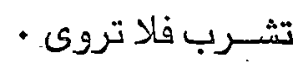

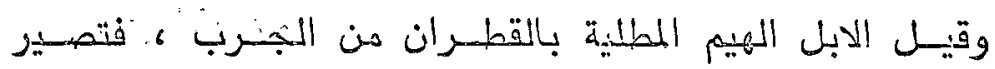

$$
\text { عطشى من حسرارة البهـرب ) . }
$$

وقد قال ابن عمسر رضى اله عنسة لنواسي : استقها أى ارتجهمها

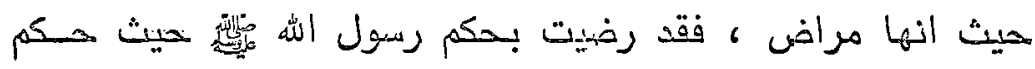

$$
\text { آلا عسدوى }
$$

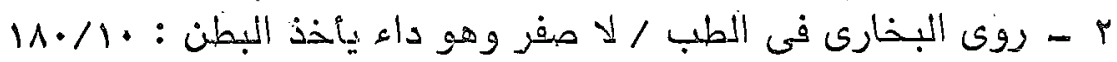

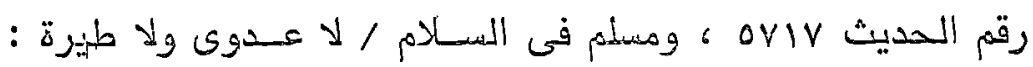

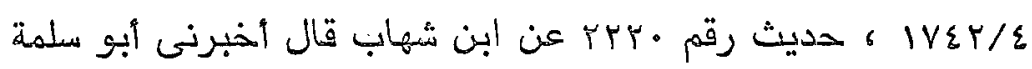

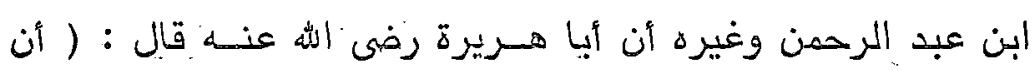

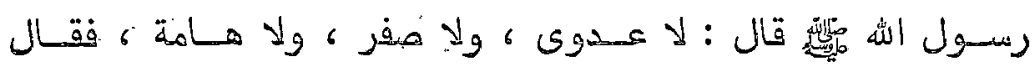

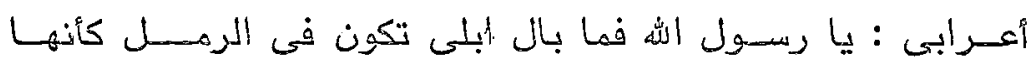

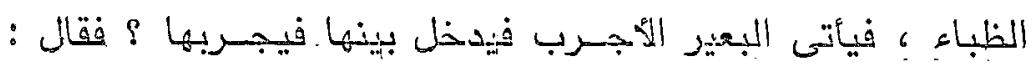

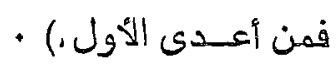
قال فى الفتح: :

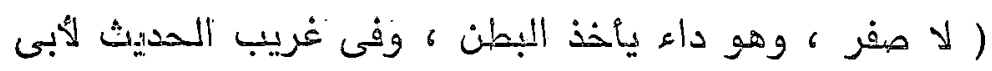

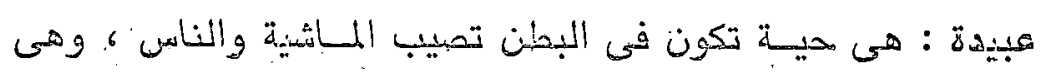

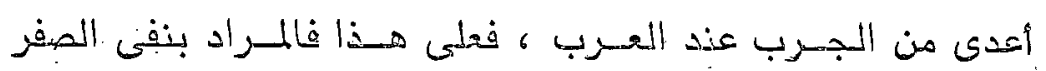

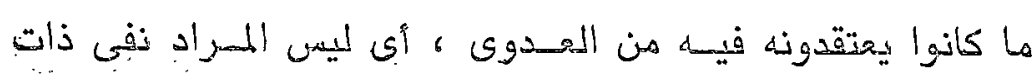

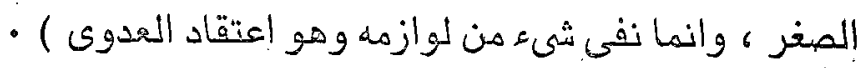
وهذا الحديث قد أخرجه البخارى في أكثر من موضع • 


\section{$-b^{2}$}

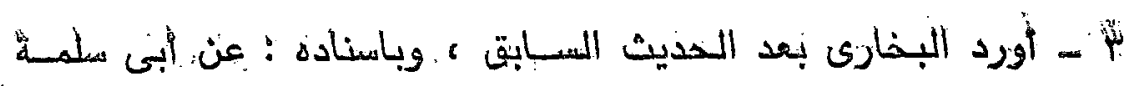

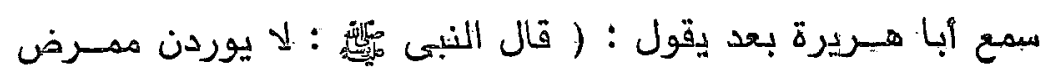

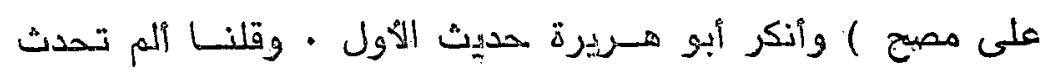

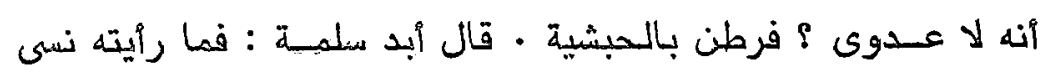

$$
\text { . حديثاغيره. }
$$

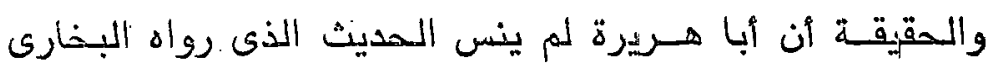

$$
\text { ومسلم ( السـابق ) والذى فيه اثبات المعدوى : }
$$

ـ لإنه رضى الله عنه هو الراوى لأكثر أجاديث المعدوى •

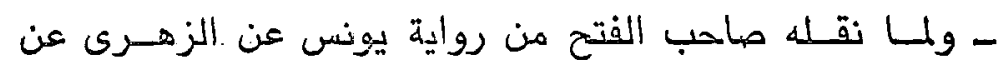

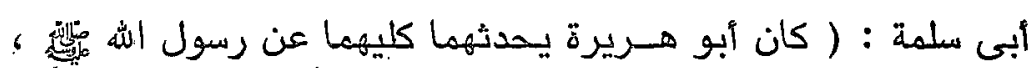

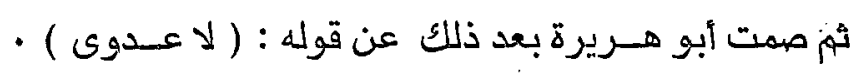

ففى رواية يونسى : فقال الحازث بن أبى ذباب وهو ابن عمم أبى : قدى

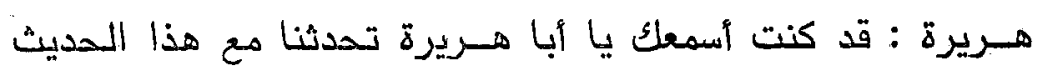

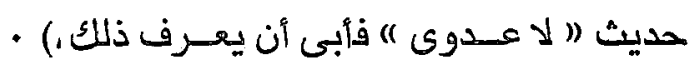

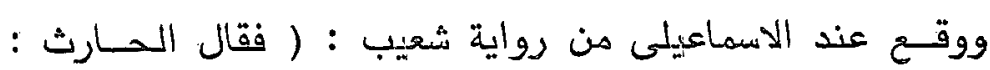

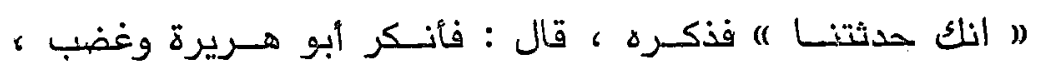

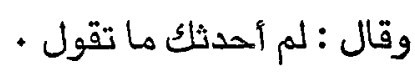

( قال أبو سلمـة : ولعهـرى لقد كان يحدثنا بهـ ، فمبا أدرى أنسى

$$
\text { أبو هـريرة ، أم نسخ أحدالقولين اللآخـر ) ) }
$$

وقال صاحب الفتح : ( وهــذا الذى قـاله أبو سلهـة ظاهر فى أنه

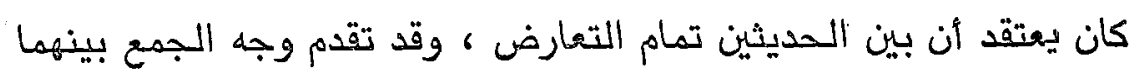

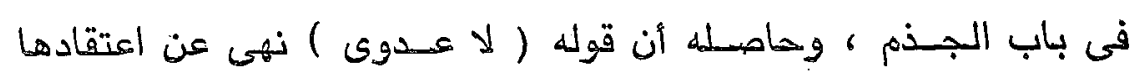

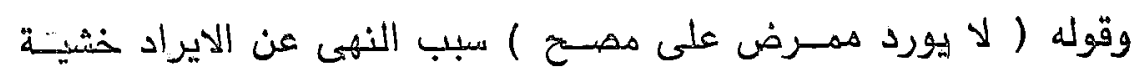

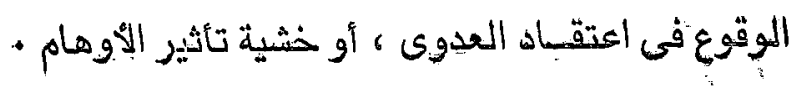


قالل القـرطبى فى ( المفهم ) : ويحتمـل أن يكون خاف اعتقـاد

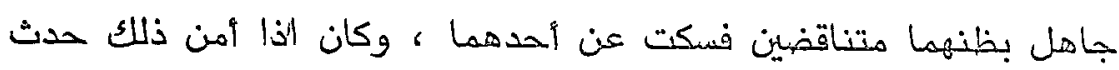

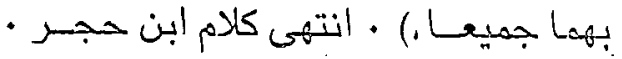

- ' ' ولذلك فان أمير المؤمنين الامامز البخارى : فمبل المديثين ، وهما تاليان في تخريجهما ، واسنادهما واحد ( رقما ovve ، ovr )

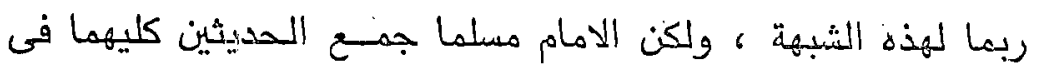

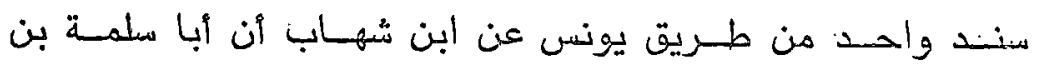

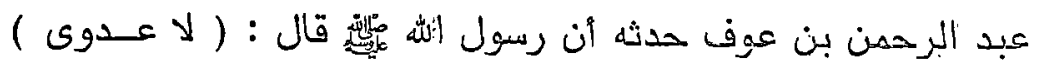

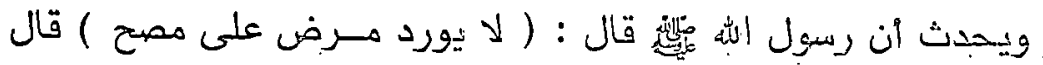

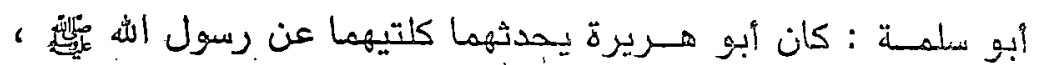

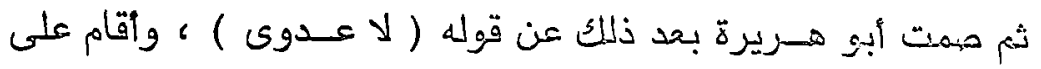

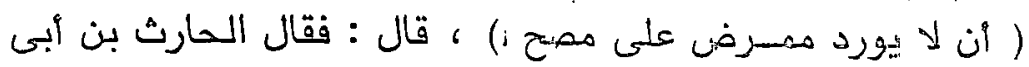

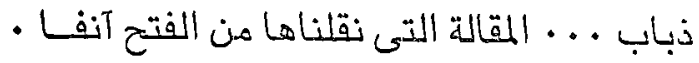

ورواية مسيسم هـذذه في السـلام / لا غدوى ولا طيرة ولا هـامة : IVIr/ع . .

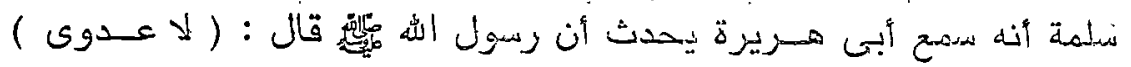

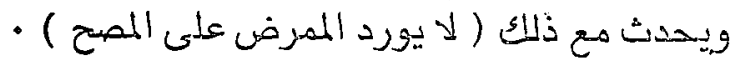

ومن هـذا يتضحح أن حديثى اثبات المعدوى ونفيها مزويان عن أبى

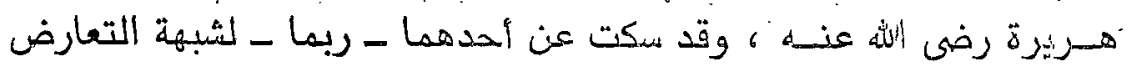

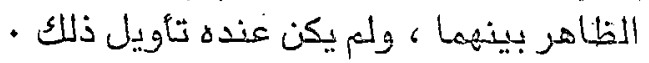

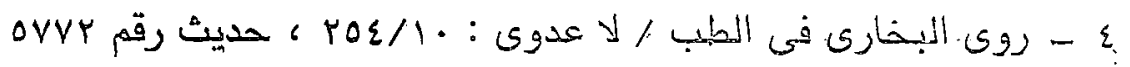

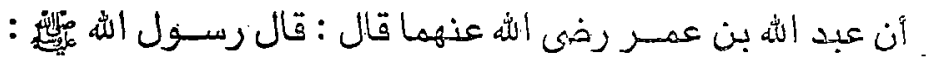

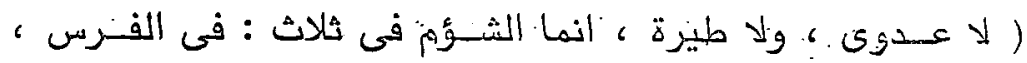

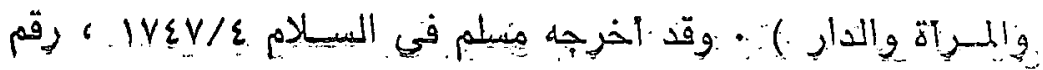




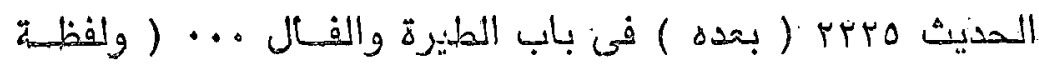

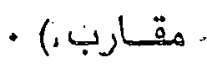

وأخرجه البخارى فى الباب حديث رقم OVVY عن أنس رضى الله

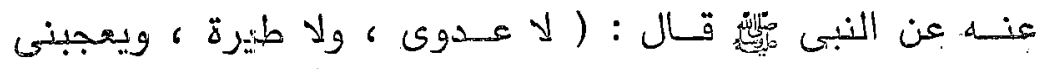
الفـأل ، قالواوما الفــال ؟ قِال : كامهة طيبة ) •

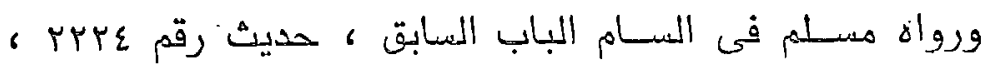

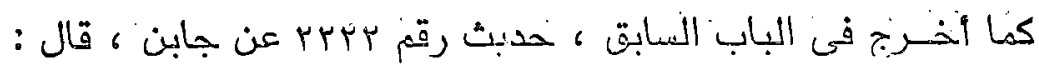

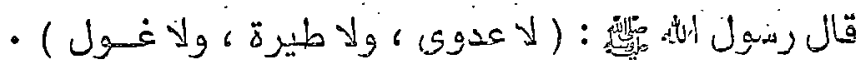

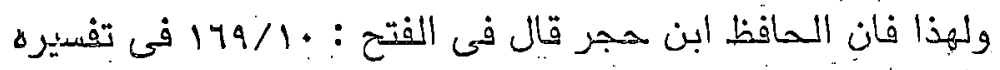

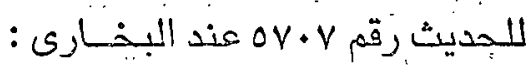

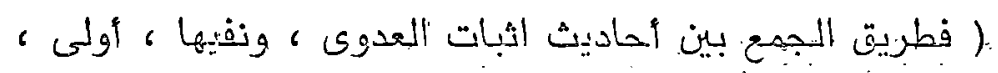

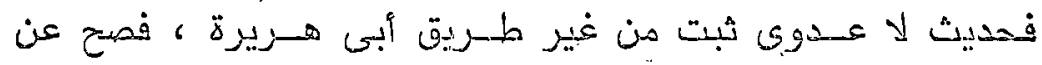

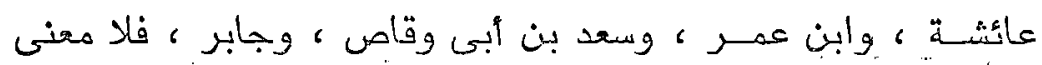

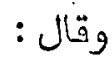

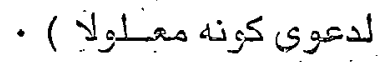

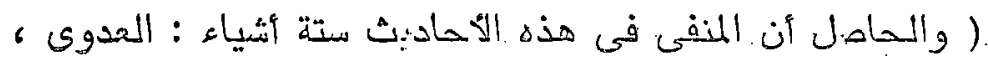

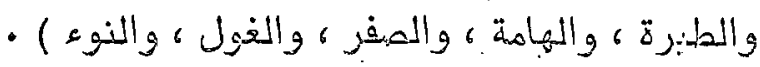

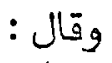

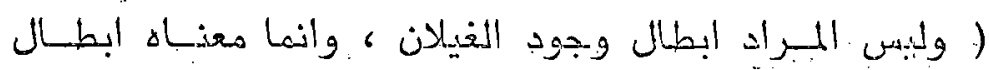

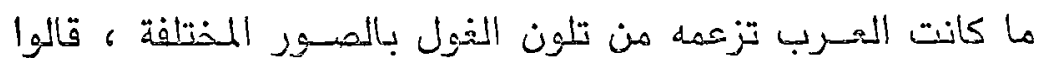

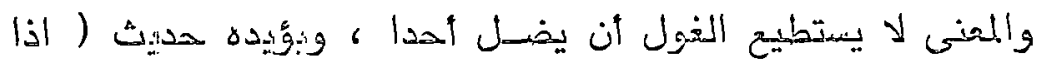

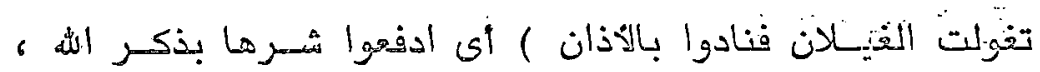

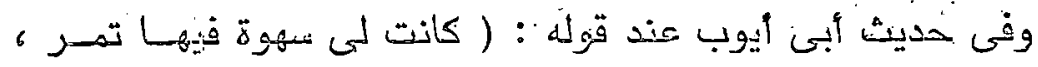

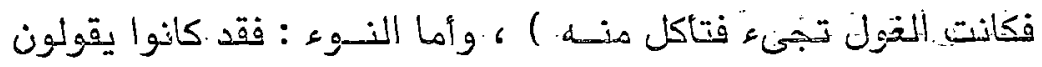

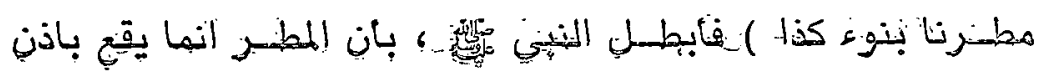




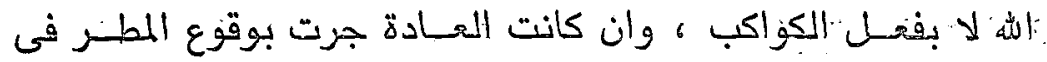

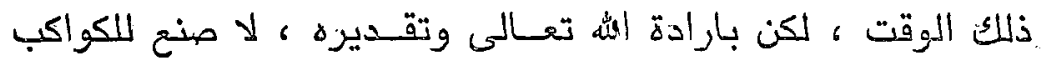
فى ذللك ) م ن ويشـير الـمافظ بذلك الى أن المنفى فنى أحاديث سيدنا رسول اله

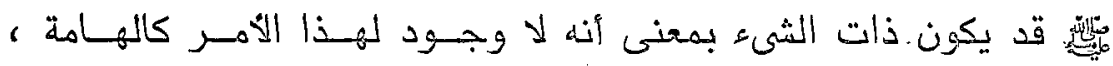

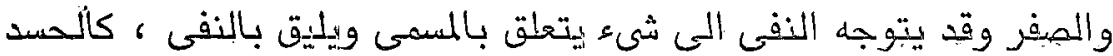

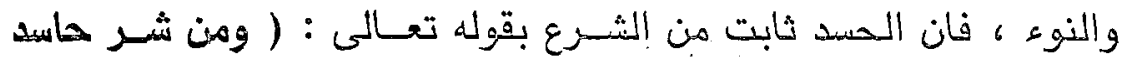

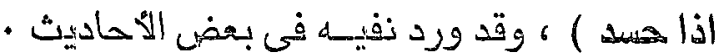
والنوء هوجود ، ويكون النفى متوجها المى اعتة ماد كونه هو المبب الفاعل بذايته في نزول المطبـر ونخلمص هن هـذا كله المى أن رأى جهمهرة المحدثين : هو أن جميح

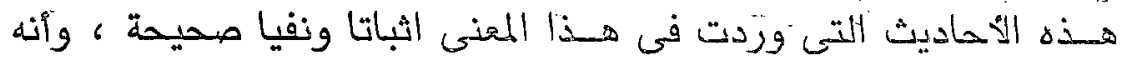

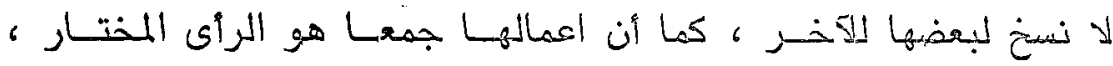

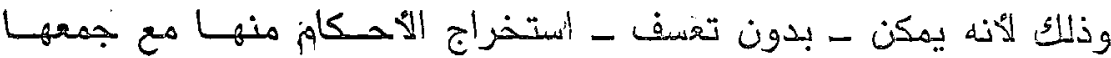

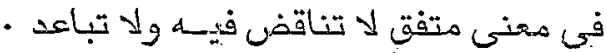

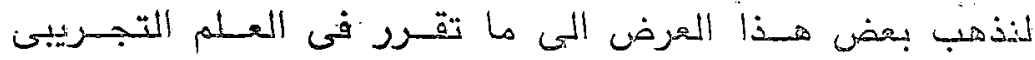

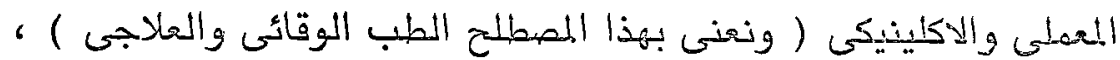

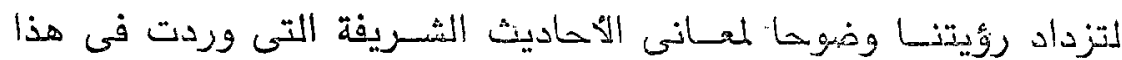
البـاب .

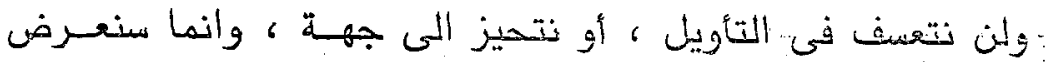

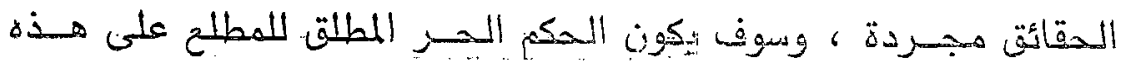
المقائق هو الاختيار الذاتى والمنطقى له :

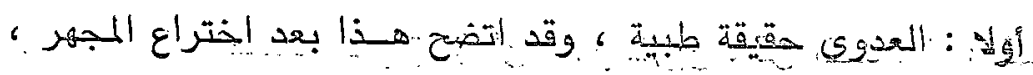

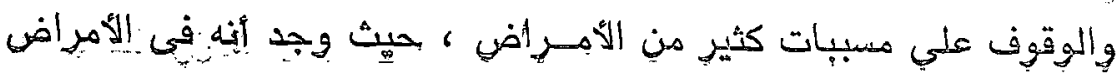


البعدية توجد كائنات لطيفة لا ترى الا بالمجاهير المكبرة ( قد تصل قدرتها التكبيرية الى أكثر من مليون حجمي ) - هذه الكائنات توجهد في دمهاء

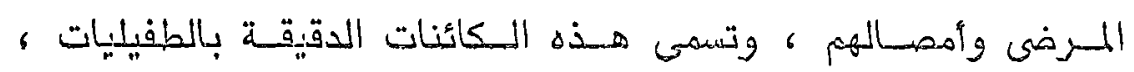
والميكروبات ك والفيروسات

ولكن مسرض فصيلة معينـة من هـذذه الكائنات لها صفاتها ، وطرق

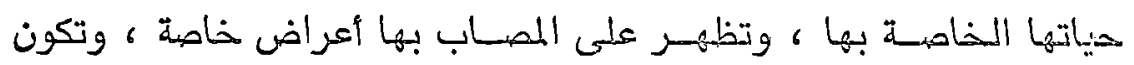

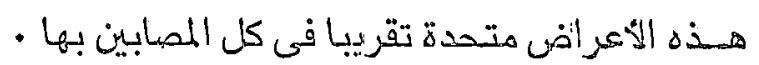

وللتأكد من هـذه الحقيقة فقد توصهل العلمــاء الى هـذه النظرية Kock's Postulates و ت فما هى أسسر هـذه النظبــرية ؟ ـ- أولا يسحب من المصاب بالتيفود ( مثـلا ) كمية من دهـه عن طريقي

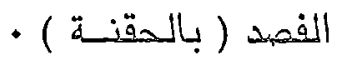

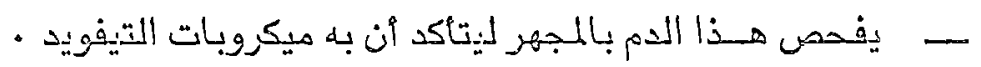

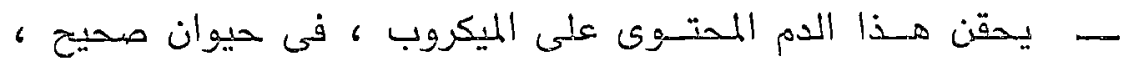

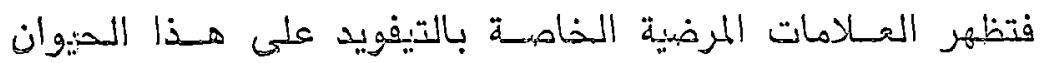
- حisall

- يسحب بهض الديم من هـذا الحيسولن ، فيوجد أنه يحتوى بملى

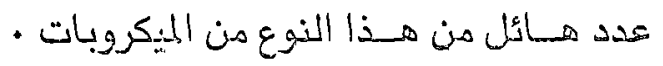

وهن هـذا ثبت وتاكك أن الأمسراض المعدية تسببها أحياء دقيقهـة خاصة لكل مرض ، وهذه حقي:قة علميـــة.

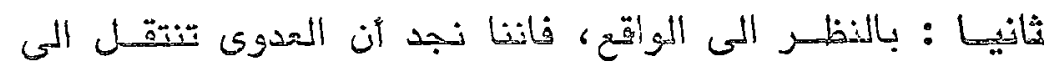

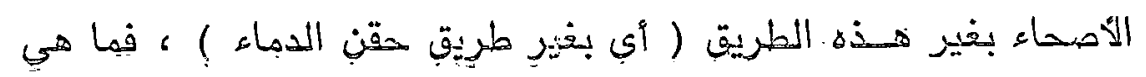
ه 


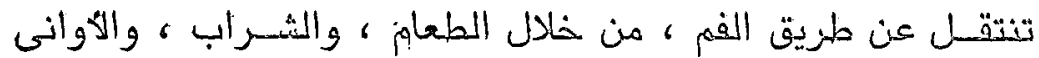

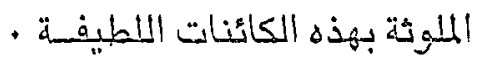

كما تنتقـل عن طريق اللانف ، منخلال هواء الاستشاق و'الذى قد يكون محتويا على كثير منهـا ، كميكروب السـل ، وفيروس الانفلونزا . وتنتقل عن طريق الجلد بالملامسة ، وارتداء ملابس وأحذية المصابين

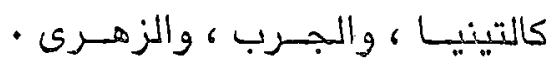
وتحمـل الحشيرات كالذباب ، والبعوضل ، والبراغيث ، والقمـل ،

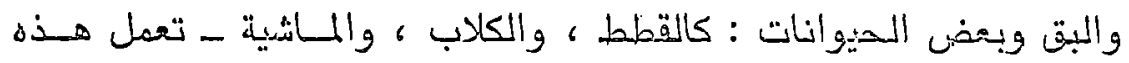

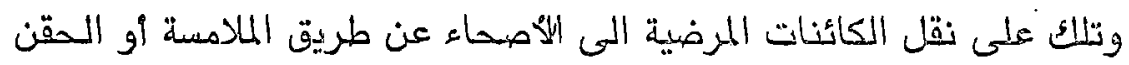

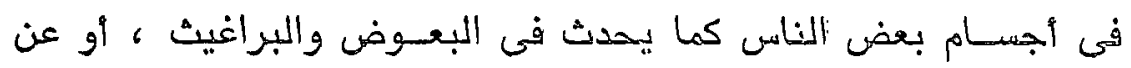

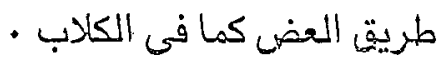
والبكتريا : كائنات حيــة دقيقة ، بسيطة التركيب ، لا ترى الل من

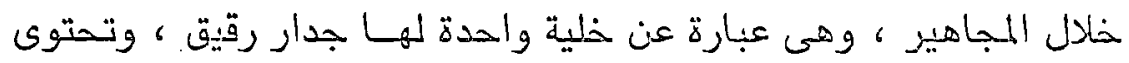

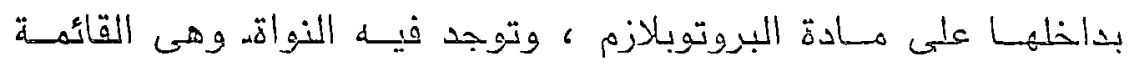

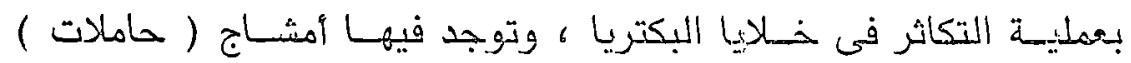

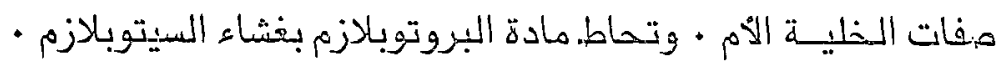
وقد يكون لهذه الخذيـة البكترية أسوانط تسـاعد على الجسركة ، وأهداب تساعد على الانتصـاق بالأنسجة التى تعيش فئهـا ، وقد تلجـا

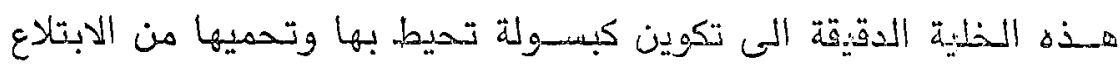

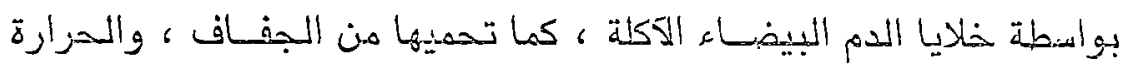

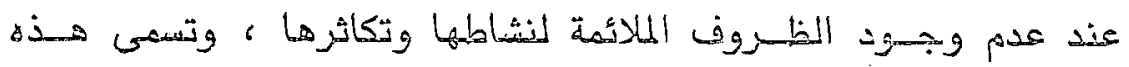
بالخلية المتحوملاة أو تسهي بالبذرة أها الفيزوبسات

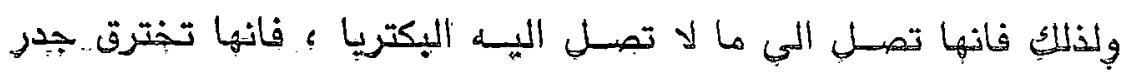




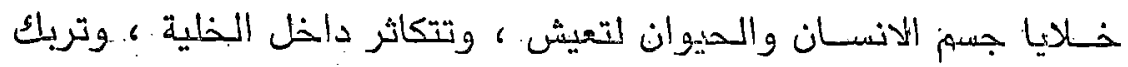
نظامها بل توظف خليـة الانسـان لنشاطها ، ويحدث هـذا كله داخل a.: الخلية التى هاجمها الفيروس •

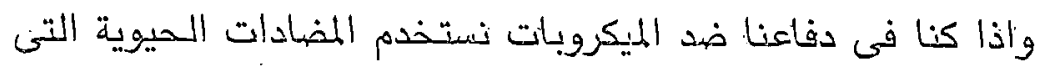

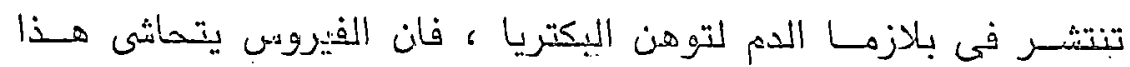

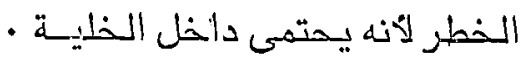

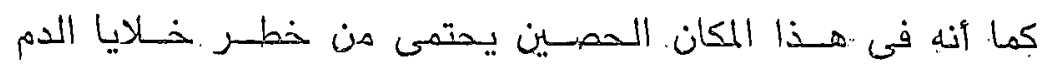

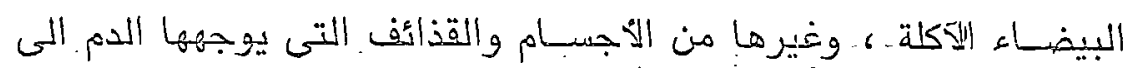

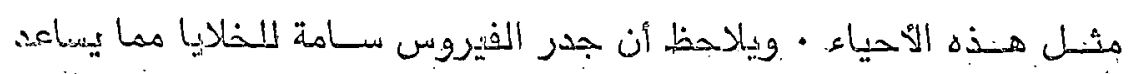

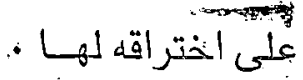

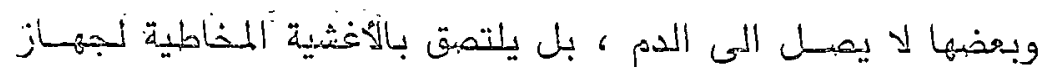

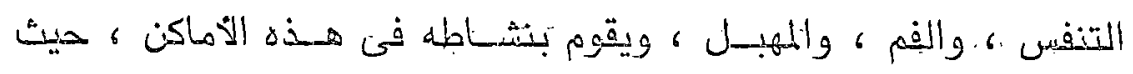

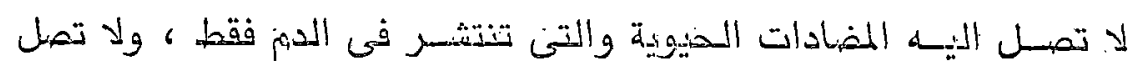

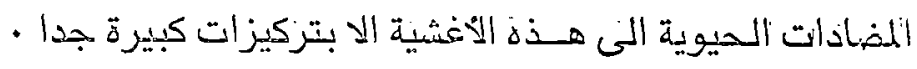

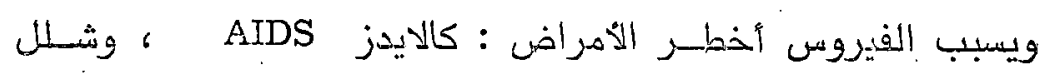

الأيفال ، والالتهاب الكبدى الوبائى ، والحمبة ، والحمى الصفراء .. وغئـرها.

ثالثيا : تقــرر علميـا أنه ليست كل فهـائل هـذه الكائنـات ـ

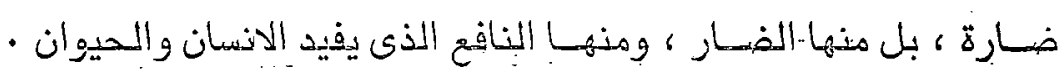

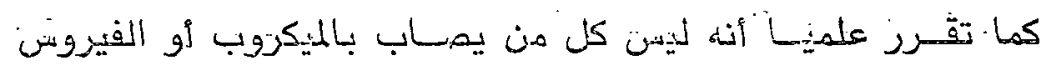

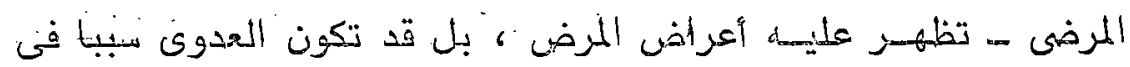

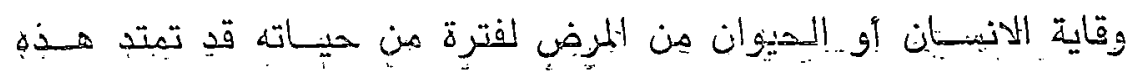

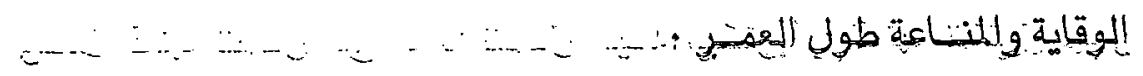


وهــنه هى نظـــرية التطويم واللقــاح ، وذلك بحقـن اللاندـــان أو الحيوان الصحيح بميكزوبات بعض الأمراض ، أو بسموم هذه الأحياء

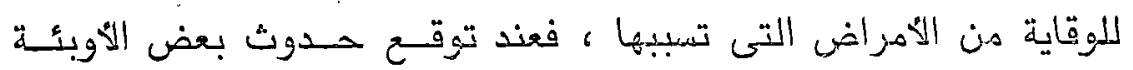

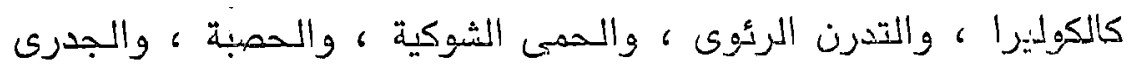

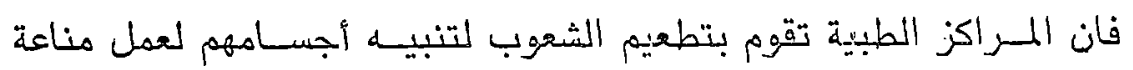

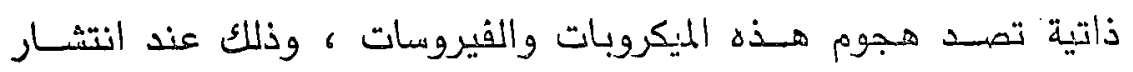

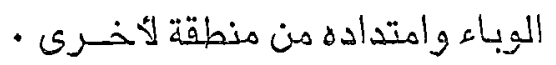

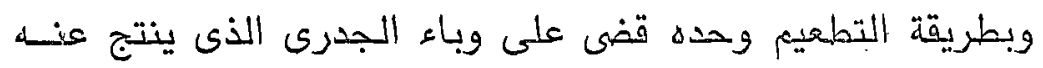

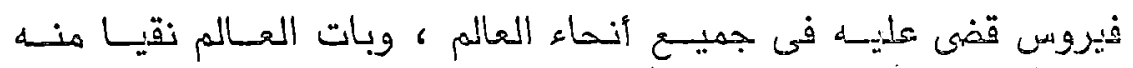

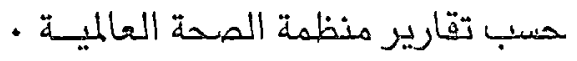

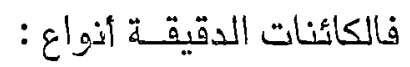

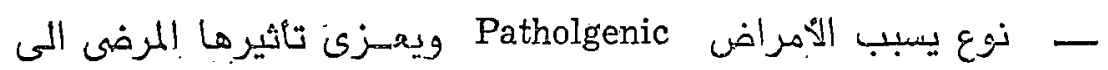

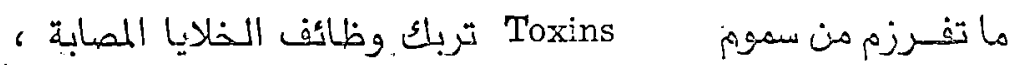
وكذا ههاجمة بعضها لأجهـزة الوقاية الجسمية والمتمثـلة في الكرات الدموية البيضـاء ، وخـلايا اللايمف ، وابطلال تأثير مضـادات

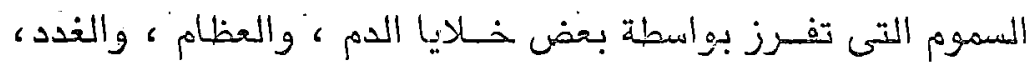

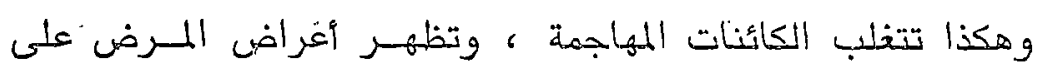
المبـاب ، ويقال الثن مريضم •

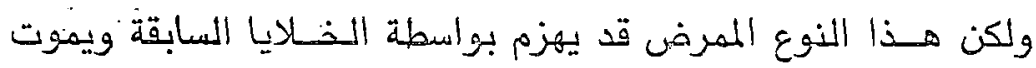

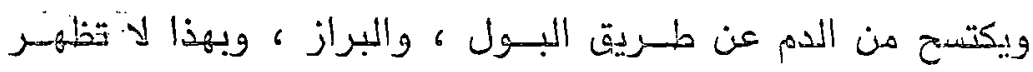

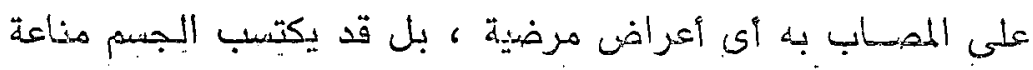

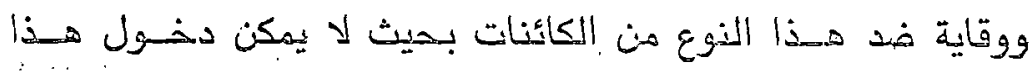

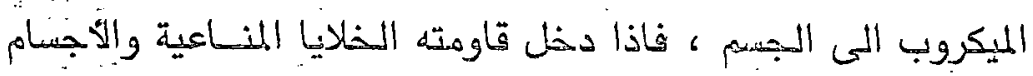

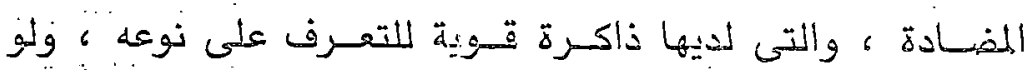

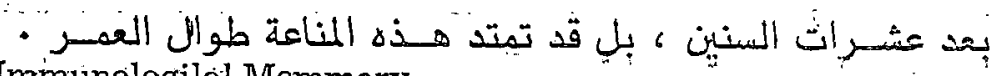
Inmunologilol Memmory. 


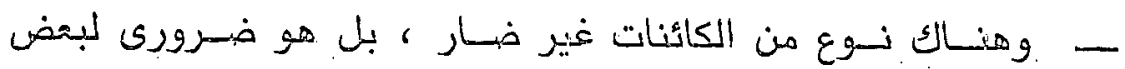

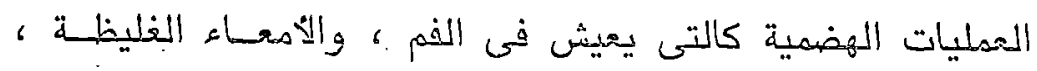

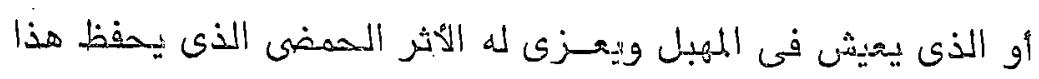

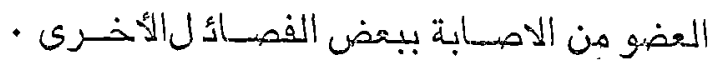

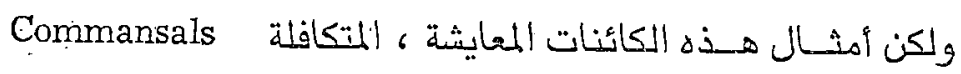

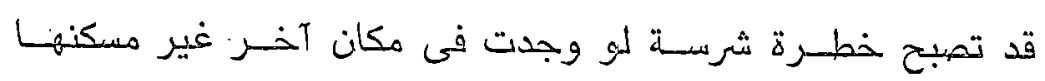

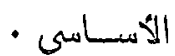

وقد تتحول الى الهجومز والفــرر فى بعض الأحوال ، كاصابة

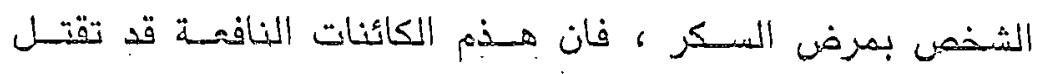

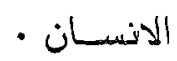

وقد تقـرر من هـذهذه الحقائق الطبية المجردة أنه ليس كل من يهاب

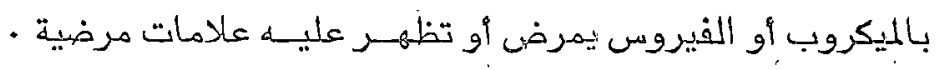
وهـذا يفهـر لنـا ما نراه من انتشتـار بعض الأمـراض البكترية

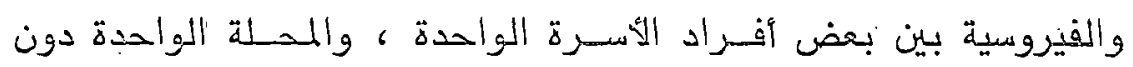
البعض الآذخر ، بل ان العـامة من الناس يقربون الأطفــال الأدهحساء

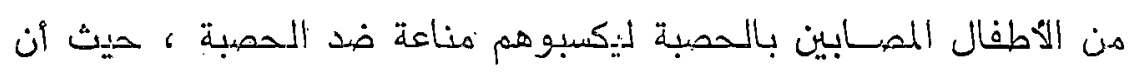

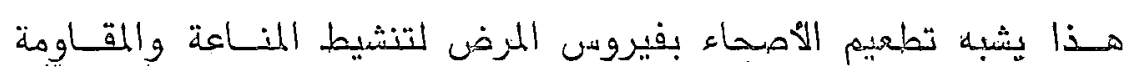

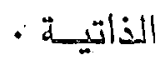

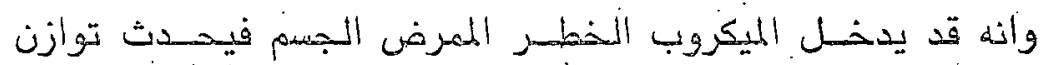

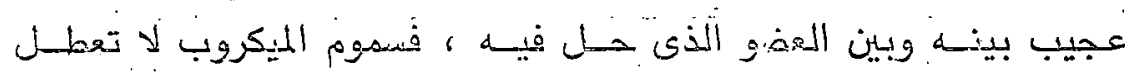

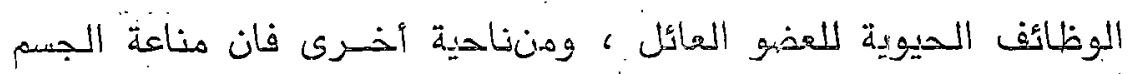

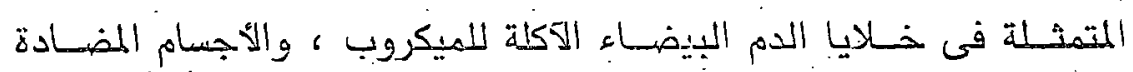

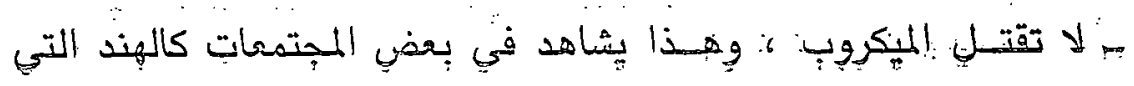




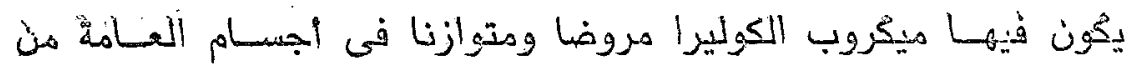

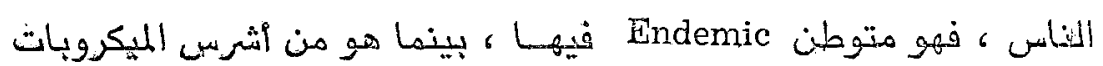

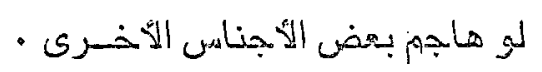

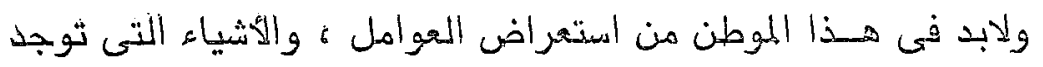

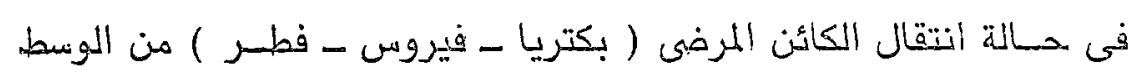

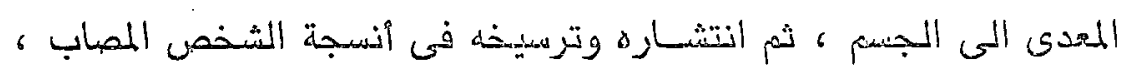

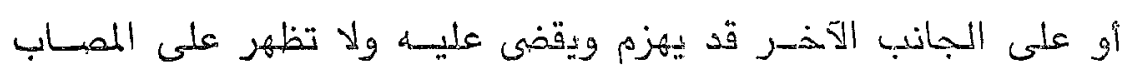

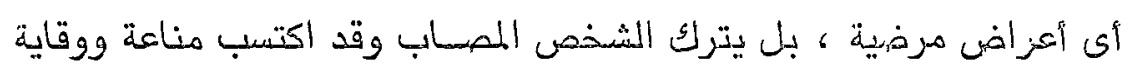

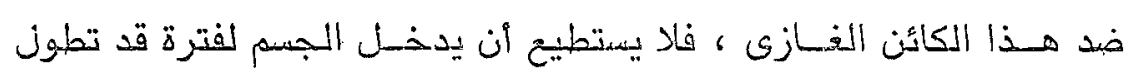

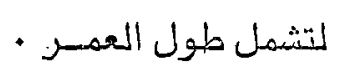

\section{عوامل خاصة بالثخص المنقول اليه العدوى ( المائل ) :}

Indavidual Factor :

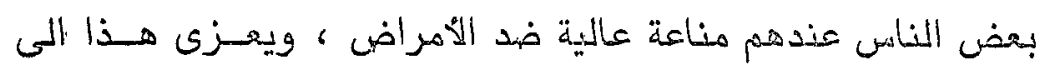

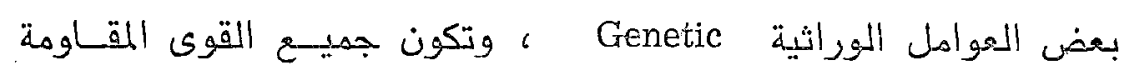
ضد الميكروبات فى أجسـامهم جنيدة - لورائ

كما أنهيوجد بحض النساس لديهم حساسية شديدة لاكتسـاب العدوى

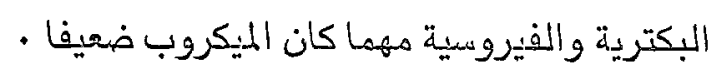

\section{Age Factor : ب ع بامل السين}

لوحظط أنه فى الشخص القهادى تكون المقاومة فى أوج نشـاطها

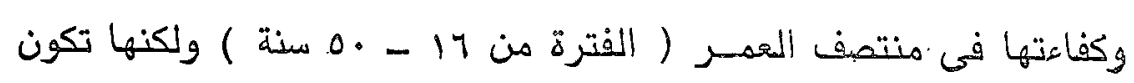

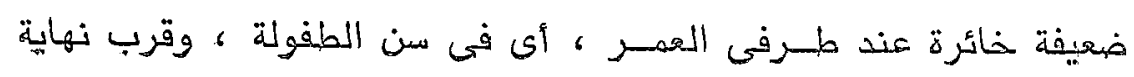




\section{$-9$}

ويعـزى هـــا الاختلاف الى نضج الجهاز المنـابى وقوته فى فترة

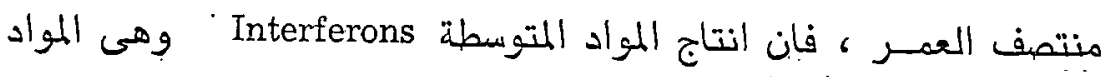
المقاتلة للفيروسات تكون ضعيفة هزيلة فى الكبار .

كما أن بعض الهرمونات والتى لهـا دور هام فى الوقاية والمنـاعة

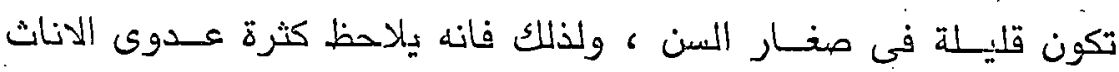

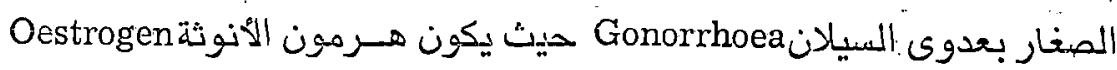

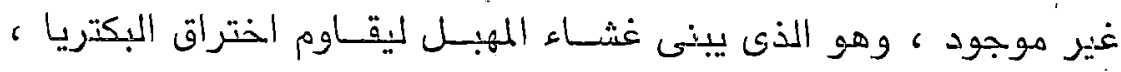

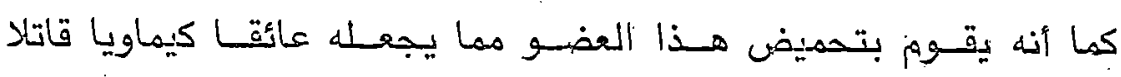

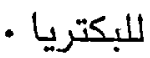

أما فى البالغات فتكون طبقات غشـاء المهبل متراكمة ، وحمضية

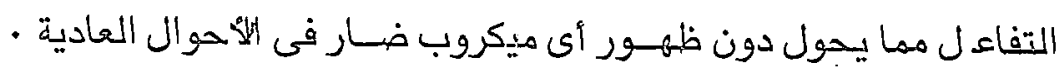

\section{Racial Factor :}

لقد تقـررت هـذه الحقيقةطبيا ، حيث وجد أن بهض بهض أجنـاس

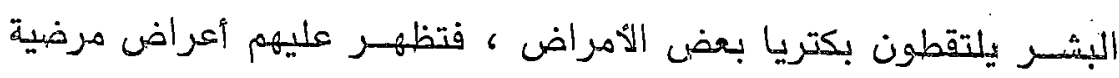

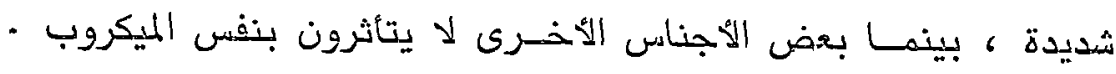
فالعدوى الفطرية Coccidio Idomyclosis تسبب التهابا فى اللأجناس السوداء

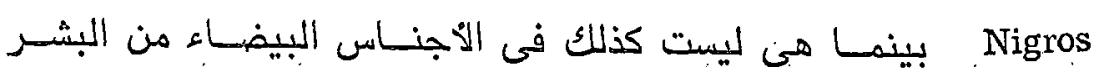
White Races $\hat{u}$

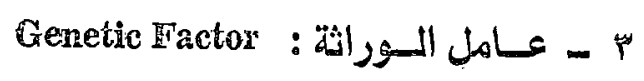

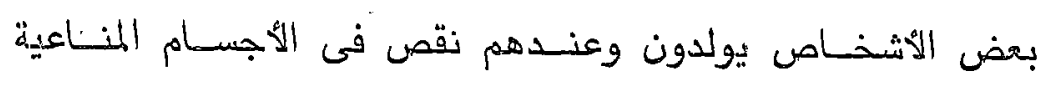

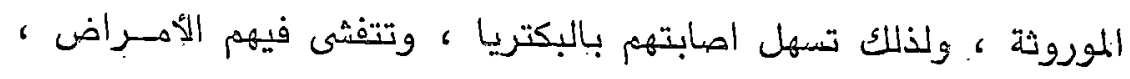

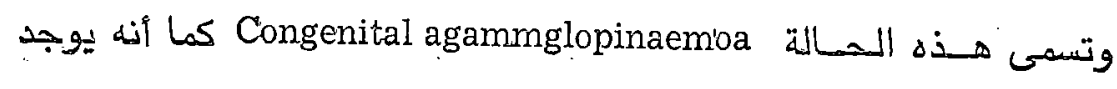

Glucose 6- Phosphate Dihydrogenase بعض الناس عندهم نقص في انزيم 


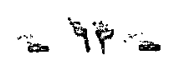

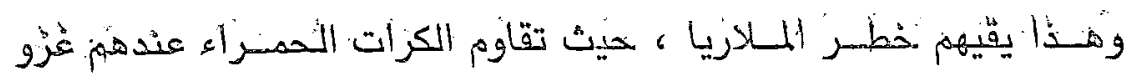
طفيل الملازيا حيث يعيش داخل هذه الخلايا .

\section{Formonal Factor : :}

كثير من الهرمونات لهـأ دور أهـادي فى مقاومة الإنسان للأمراض؛

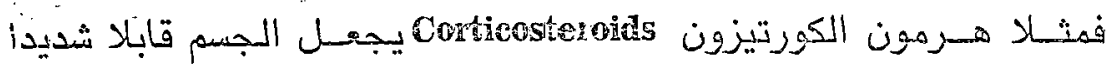

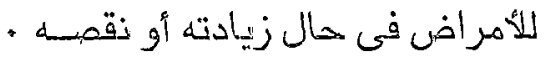

ولذلك فانه عند زرع الكلى أو القلب أو العيون فانه يعطى بانتظام

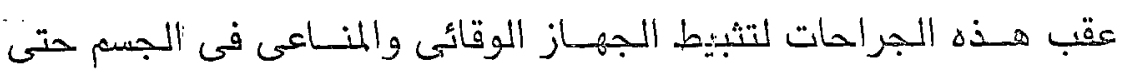

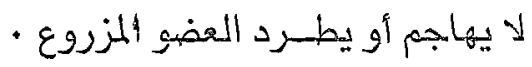

فالكورتيزون يثبط الأجسـام المنـاعية Artibedies والتى تقـاوم

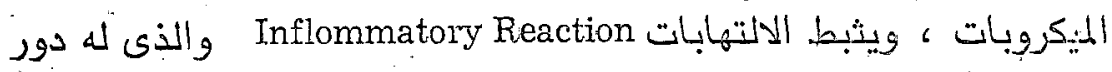

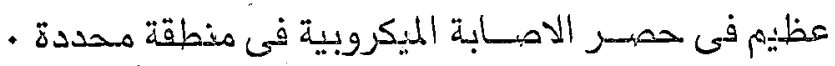
وكذلك فـانه يثبط المتوسطسات Interferons وهى التى تقــاوم

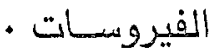

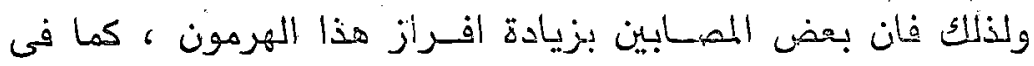

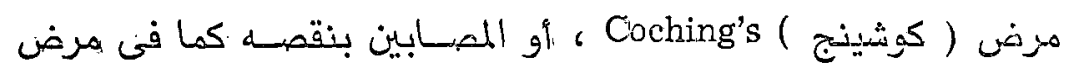

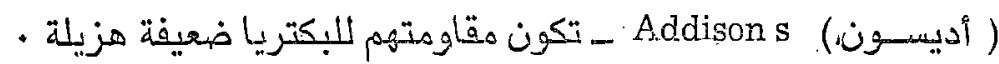

كما أنه توجد عوامل كثيرة غير هـذهذ تجـل عن الحميـر ، تؤثر

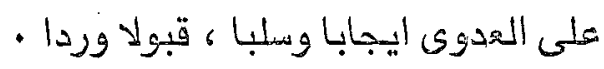

ففى بعض ألاضطرابات الهضمية ( الهضنم والامتصاص - التمثيـل

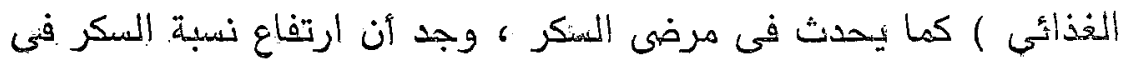




\section{$-9-$}

الأنبسجة عسامة ، وفىى الدم ، فان الخـلايا الدهـوية البيضـاء الأكـلة

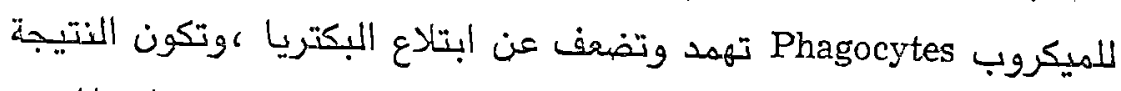

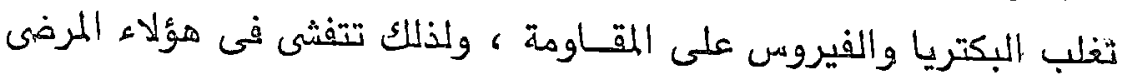

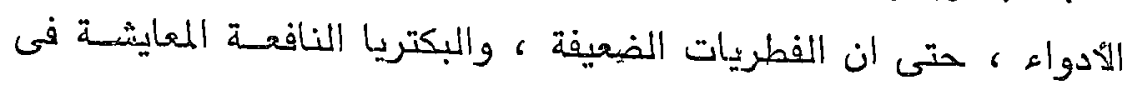

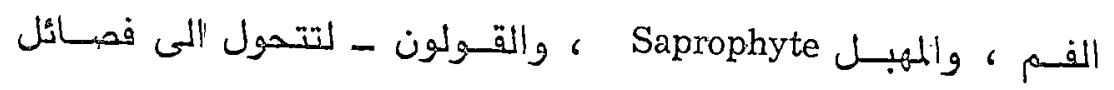

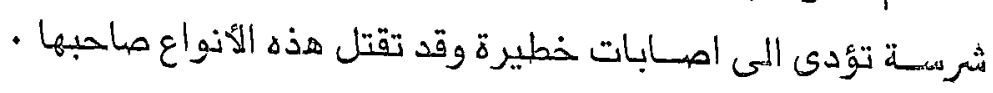

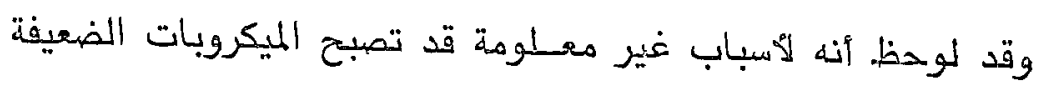

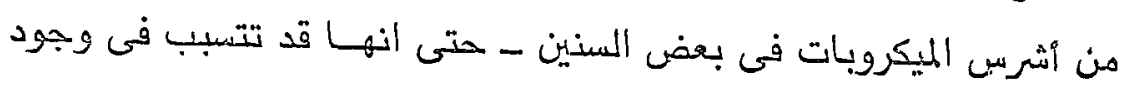

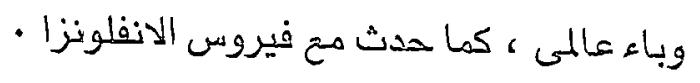

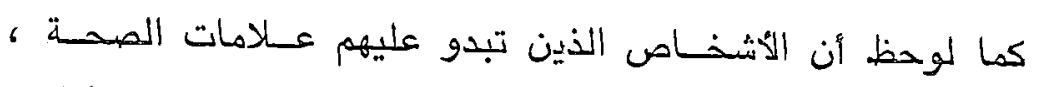

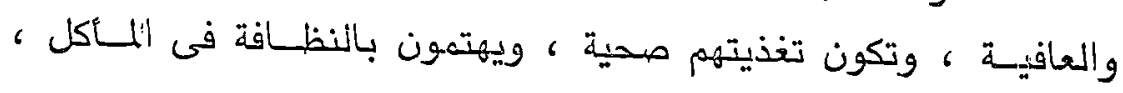

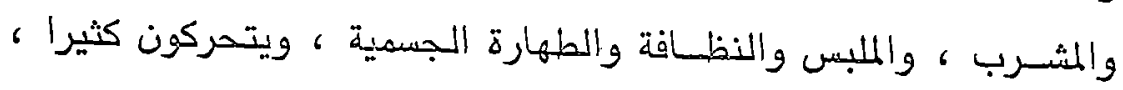

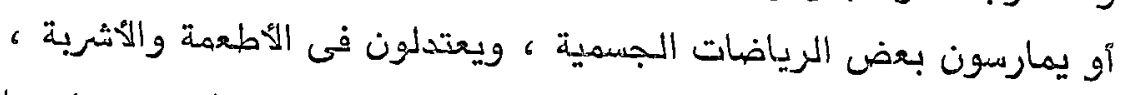

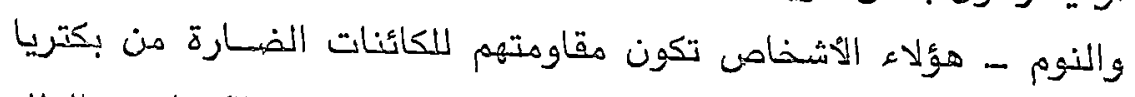

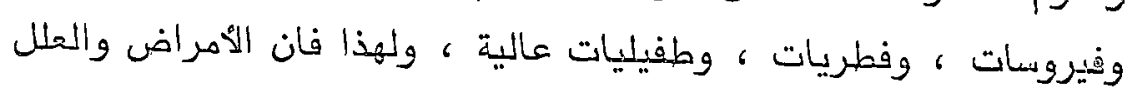
تندر بينهان •

ولا يفوتنا عند هـذذه النقطـة الى أن نتبـهـ الى أن الاسـلام المنيف

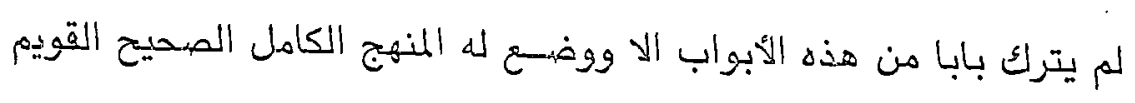

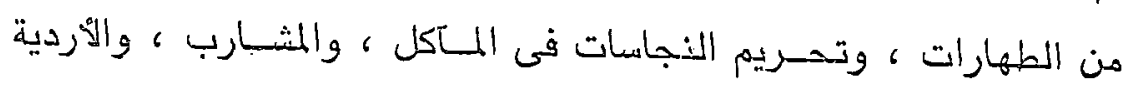

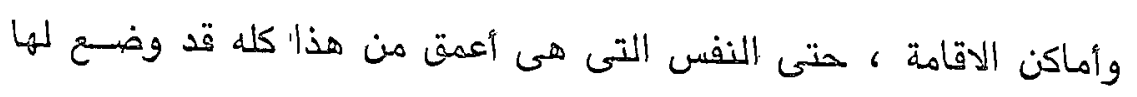

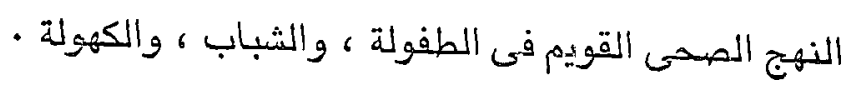

فاذا انتقلنا الى ناحية أخسرى ، فانتا سوف نجد أنه في الثخحص

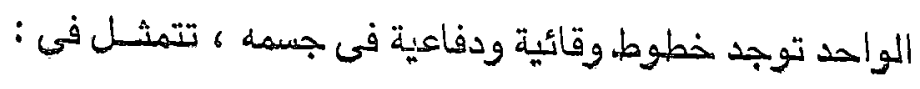




$$
=9^{\circ}-
$$

• خطوط دفاعية تركيبية تشـريحية (i )

$$
\begin{aligned}
& \text { ( ب) - بوفسيولوجية } \\
& \text { - ( ) وكيميـائية }
\end{aligned}
$$

\section{أولا : الدفاعات التركيبية ، وتتمثنل فى :}

1 - الجـلد : فان البيئسة المحيطة بالانسان والتى يموم ف:ها كمن يمويم

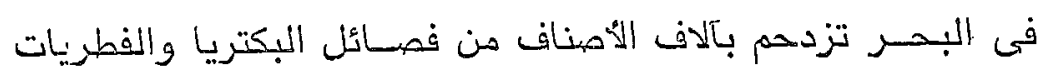

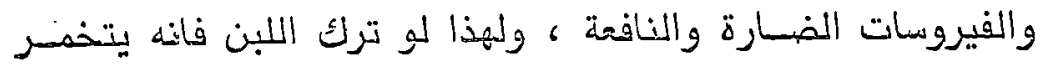

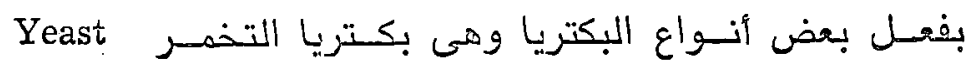

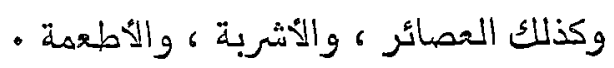

ولكن الجلد الذى يلف الانســان والحيوان ، يتكون من طبقات متراكمة تحول دون اختراق هـذا الجــار الركامى بواسطة هذه

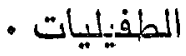

وكـذلك فــانه يحتـوى على غــد تفــرز مفـرزات شهميـة Sebacious Secretion دهنيـة ، وأنزيمات محللة للبكتزيا فيحطم الجدار الخلوى للكثير

$$
\text { Lysozyme من البكتريا }
$$

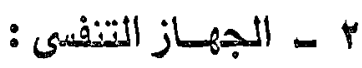

وهو هدف أسـاسى ، وطريق رئيسى لنـزو الأحيـاء الدقيقــة عنّ

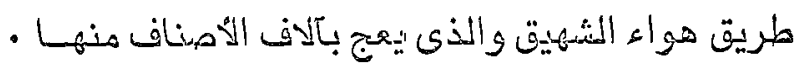

ولكن الله تعسالى قد أختص هـذا الجهاز بوسـائل دفاعية تركيبية

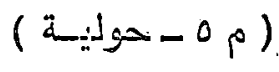




\section{$-19$}

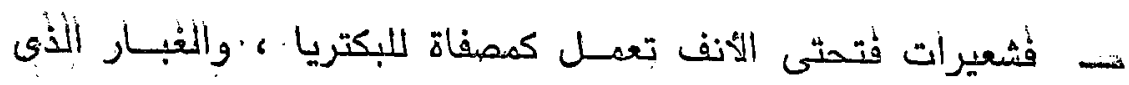

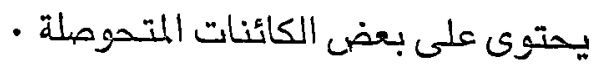

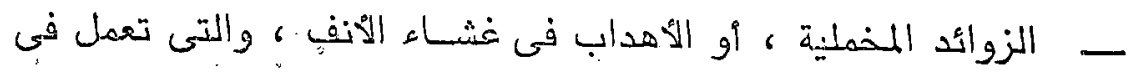

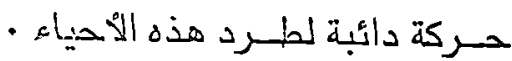

ــ - ما يحويه مدخـل هـذالال جهاز من مخاط يحتوى على مواد قاتلة.

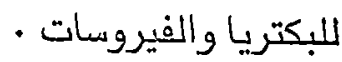

العطس Cough Reflex والذى يطرد كثير امنها دفعة واحدة :

r "- الفـين : تحتوى الدموع على أنزيمز قوى Lysozyme يقتل البكتريا.

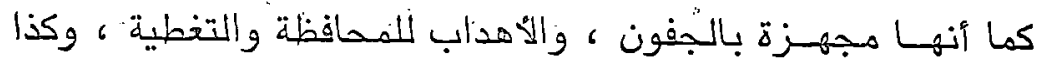

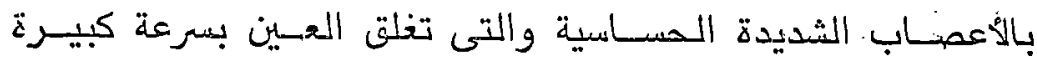

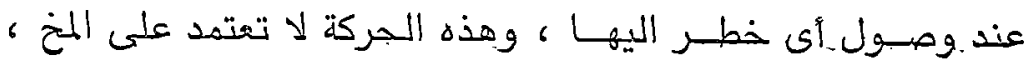

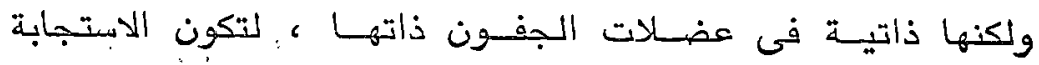

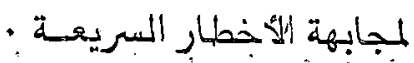

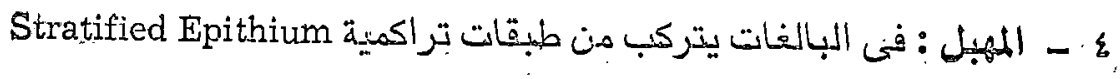

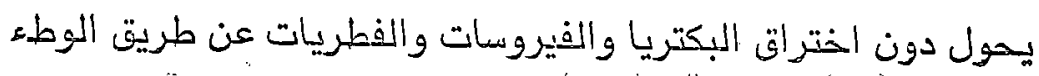

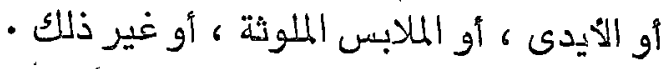

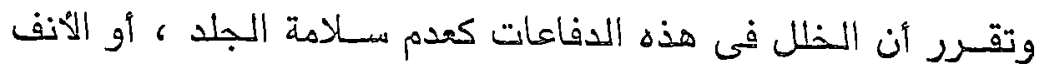

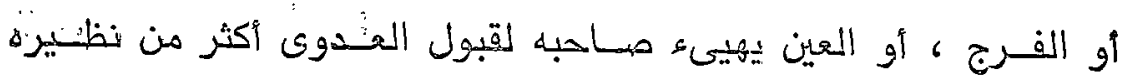

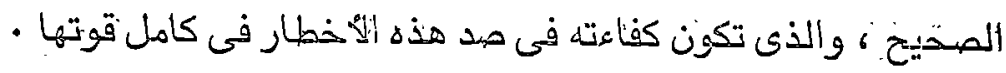

\section{ثانيـا : الدفائات الفسيولوجية" ، وتتمثل فيل :}

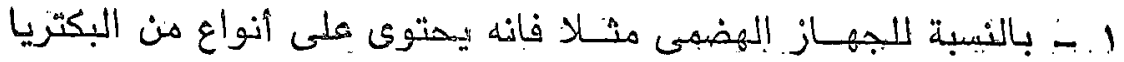

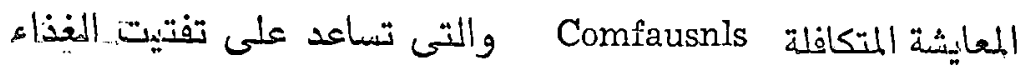




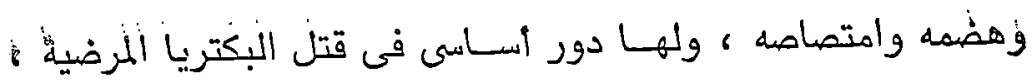

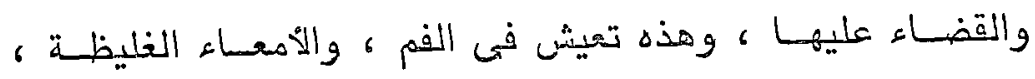

\section{وتسمى كذلك Soplophytes}

r - تعيش فى المهبـل بكتريا التخمسر Lactobacillus وهـذه بكتريا

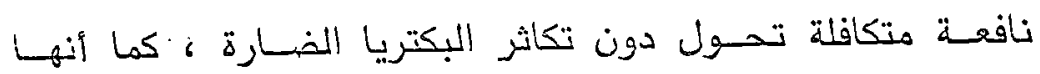

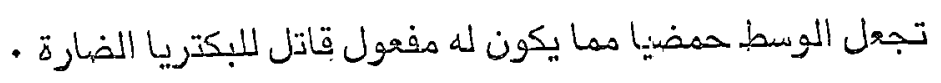
ولذا فان الفتيات الصفيرات تقلل عندهن هذه المتكافلات مما يجعلهن عرضة لاقتناص كثيرا من العدوى . r - يوجد فى المعسدة حمض اللايدروكلوريك. القوى والذى يقتـل معظم البكتريا الواصهلة مع الطعـام والثراب ، وكذلك توجد الأنزيمات

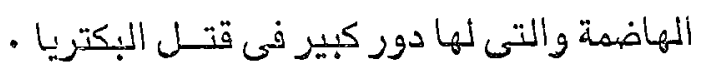

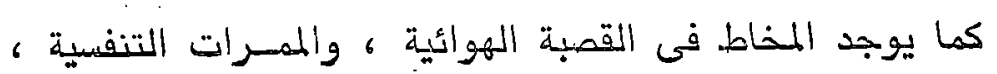
والذى يحتوى على انزيمات قاتلة .

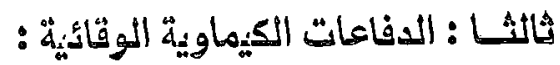

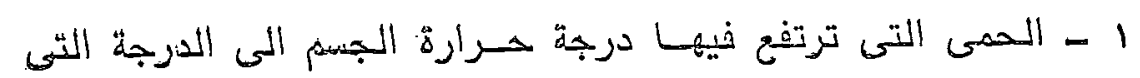

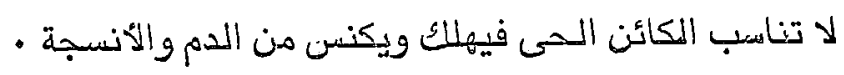
وتحدث هنـذه الحســرارة بفونـل :

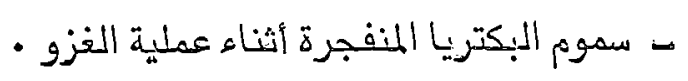

- بتأثير الكرات الدموية البيضيساء الممطمة ، ونفايات الأنسجـة

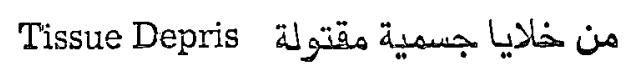

وهـذه الأشياء تنبسه مراكز المحسرارة فى المخخ ، فترتفغ درجة

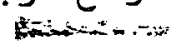

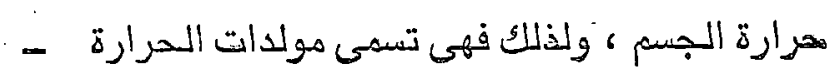

Endogenous Pyrogens 
52

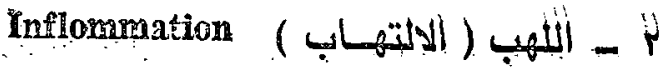

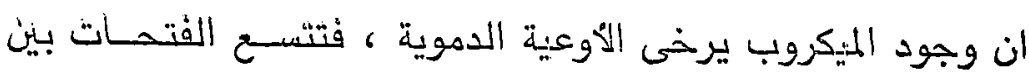

خلايا هـذه ألؤوعية ، فتززداد النفاذية ، وتصبب المواد المضهـادة للبكتريا

من داخل الوعاء الدموى الى الندنسجة التى بها الميكروب لتهاجمه وتقاتله .

كما أن البكتريا نفسها تفـرز مواد خاصة Chemotactic Substances

والتى تجـذب كـرات الدم البيضـاء Polymorphonuclear Leucocytes

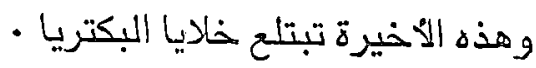

ولكن هنـاك بعض أنواع البكتريا يمفيش داخـل خـلايا الجسبم

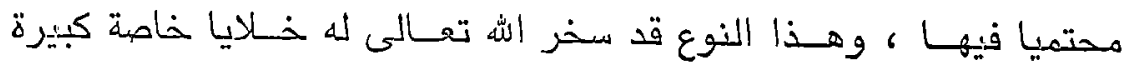

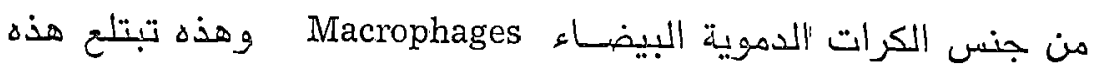

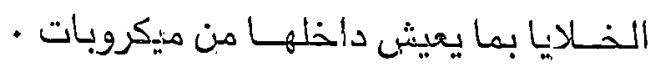

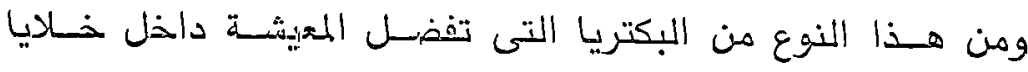

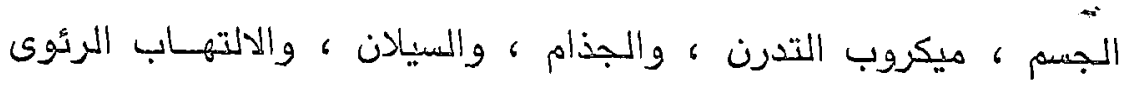

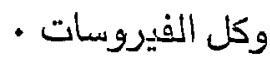

ومن الملاحظخ أيضا فى هذا الباب (الدفاعات التركيبية، الفصيولوجية

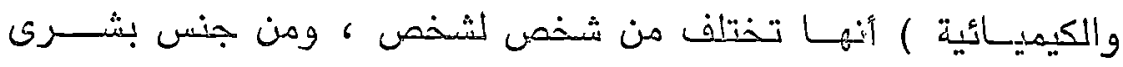

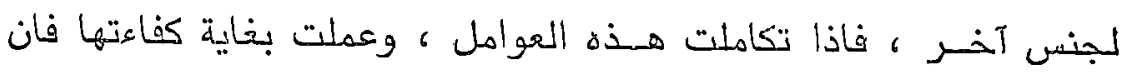

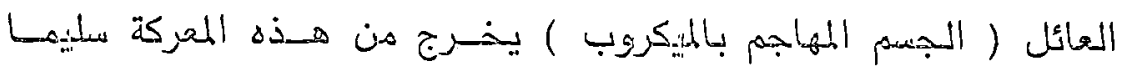

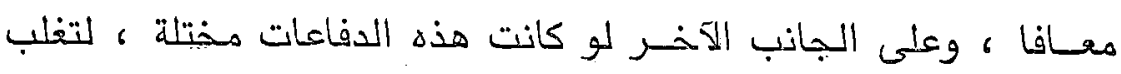

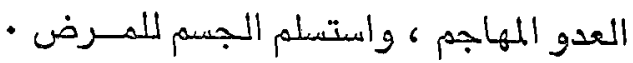

ولكن الميكروب اذا تخطى هـذه الاستحكامات ، فانه يوأجه بنظائم

دفاعى آخــر يفوق فى دقته وتخصصبه ما سبق ذكـره . ونحن بتوفيق تعالى وعونه نلخص هذا الموضوع فيما يلى : 


\section{المنـاءئة المتخهيصـة ( الجهـاز المنـاعى .)}

\section{IMIMUNOLOGICAL SYSTEM}

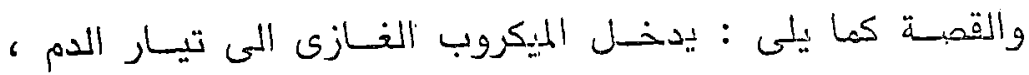

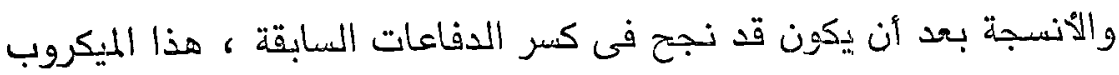

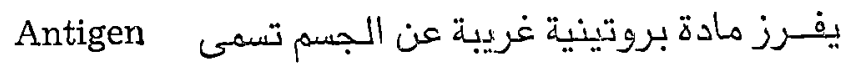

هـذه المـادة تثير الجسمللدفاع ، فتبدوأ الهجمة الأولى من خـلايا

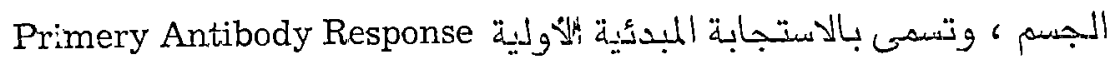

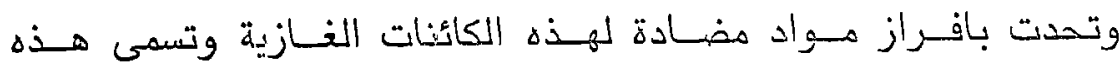

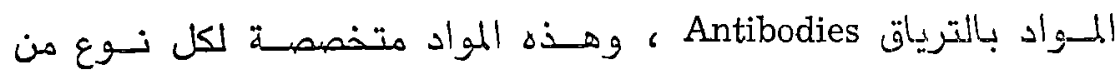

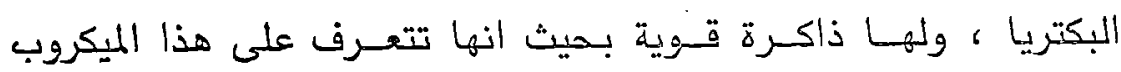
فتقاتله ولو جاء بعد عثـرات السنين . وهن هـذا النوع من المنــاعة ابتكر العلمــاء التطعيم ، واللقهـاح

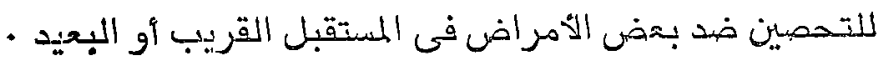
والذى يقوم بافـراز هذه المواد Antibodies الترياتية هى خلايا

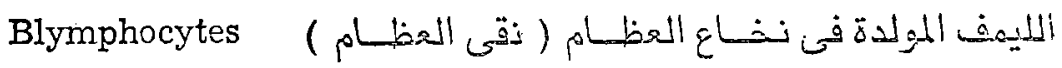

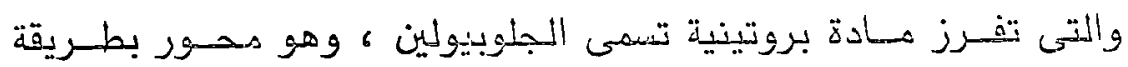

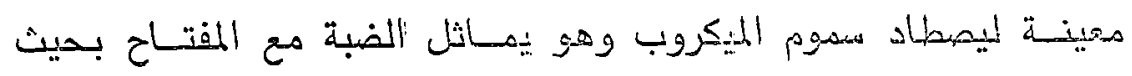
يكون لكل سنم بكتيرى ترياقه الذى يماثلك ، ويمكنه من ابطاله .

وهنـاك خـلابيا ليمفاوية أخـرى تفـرز بواسطة الغدة التيموسية

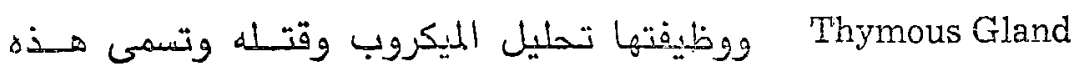
Cell Mediated Immunity

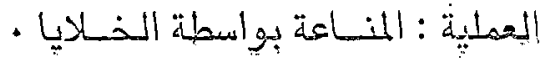


ويستمر تكون الترياق - فى الاستجابة المبدئية الأولية لعدة شهور ؛ ثم يختفى من تيـار الدم ، وتكون النتيجهـة تكون خلايا عالية التخصص

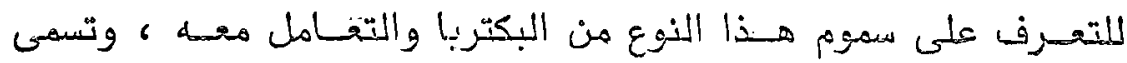
هـذه الذذلابيا م-Iymphocytes ويبدأ ظهـور الترياق بعد حوالى

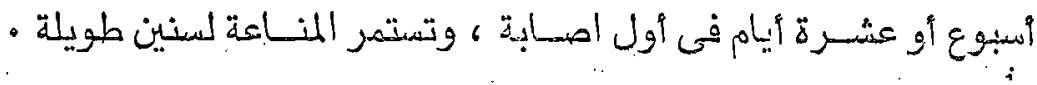

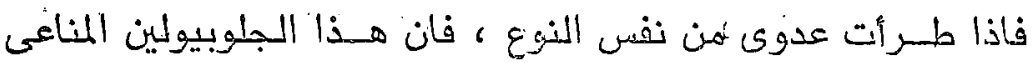
Specific Antibodies

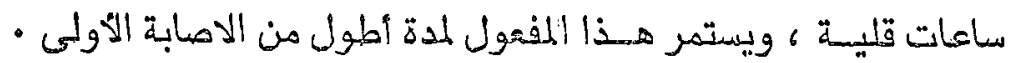

\section{وتسمى الاصسابة الليانية : باللاستجابة الثانوية المنـاعية}

Secondary Antibody Response

وتمـزي، هـذه السرعة في تكوين. الترباتى Antibodies الى الذاكرة المنـاءية Immunological Memmory والتى نتجت من الاصـابة - لปا

وقد عـرف أن الامهـابة بالجهدرى ، والحمى الصفراء ، والدف:تريا

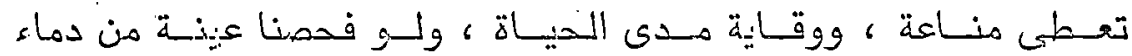

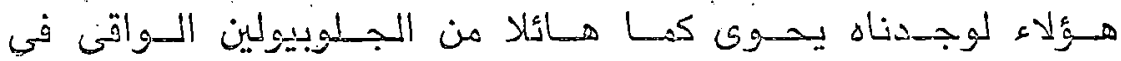

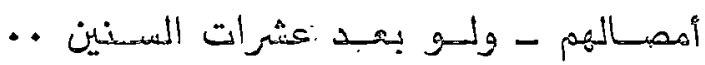

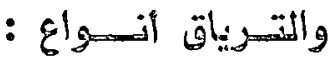

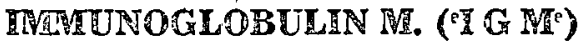

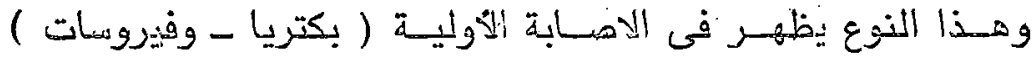

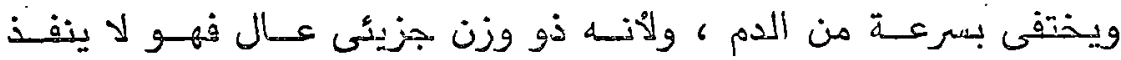

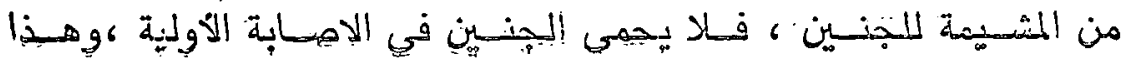




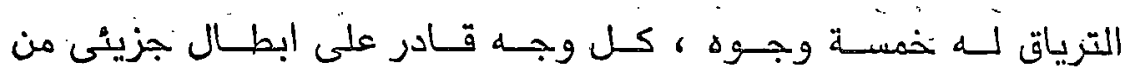
Antigen "نسم البكتريا لهوبان

\section{IMMINOGLOBULHN G ( $\left.19 \mathrm{G}^{\circ}\right)$}

$-r$

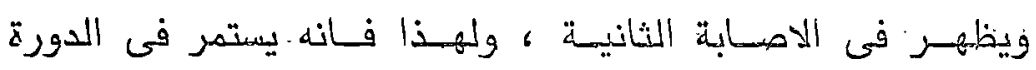

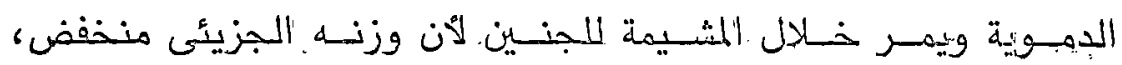

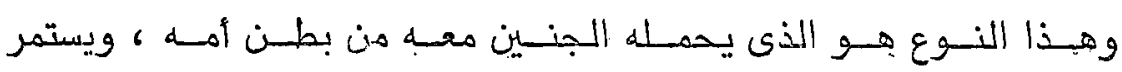

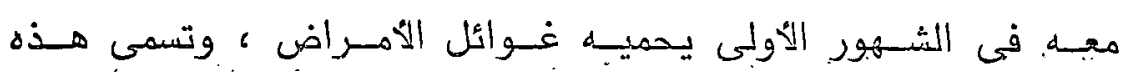

Passive Immunity

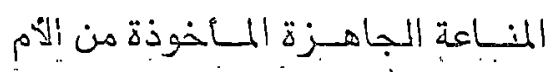
ولجزيئى التربياق ثلاث وجسوه قـادي على الاشتباك بثلاثة جزيئات

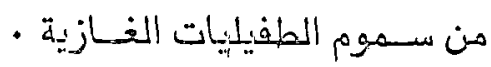

\section{IMIUUNCGLOBELIN A (ISA)}

$-r$

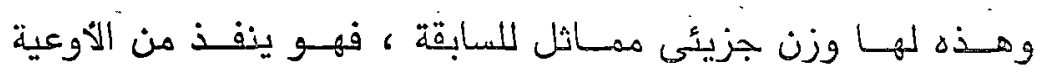

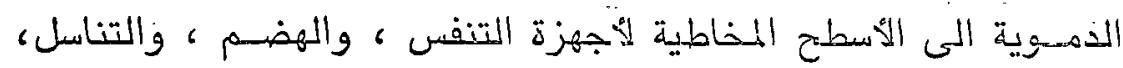

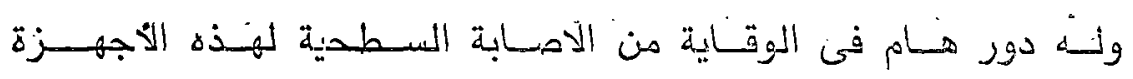
Secretory Type of Immunoglobulins

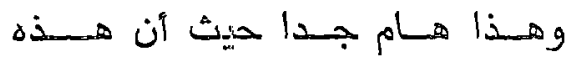

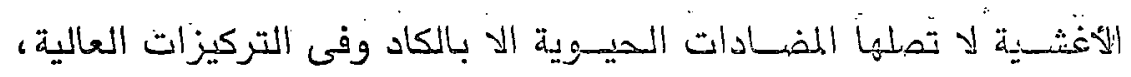

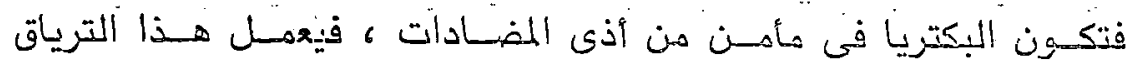

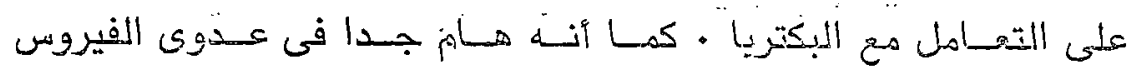

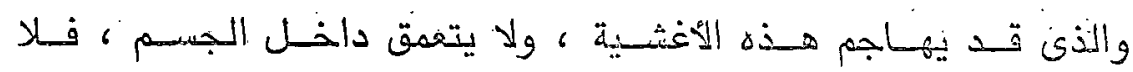

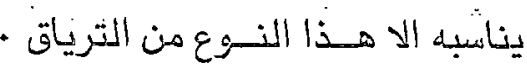

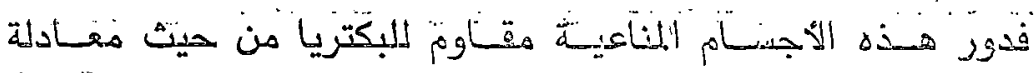

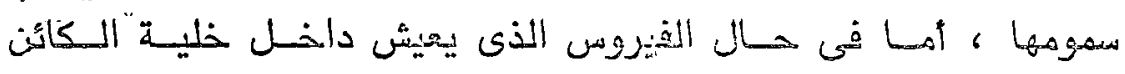

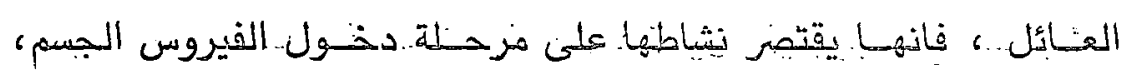

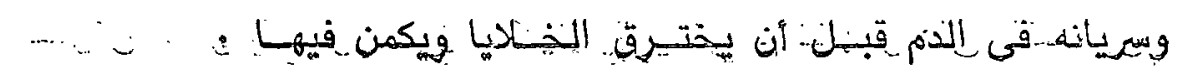


ولنضرب فيى هـذا الموطن مثـالا لتاكيد أنسه ليسي كـل هيكـروب

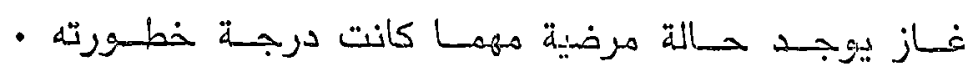

فنحن اذا أدخلنـا المـادة المفـرزة السـامة لميكروب التـدرن الى لى

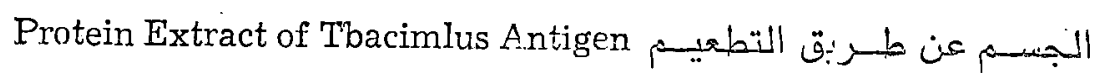

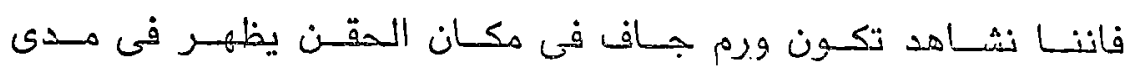

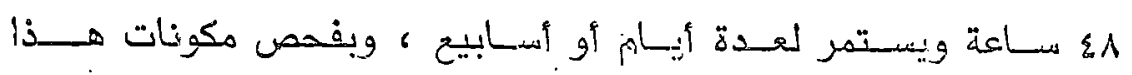

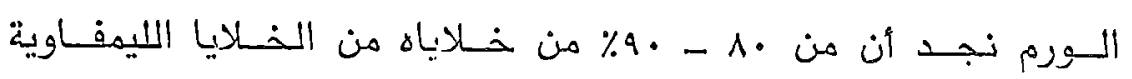

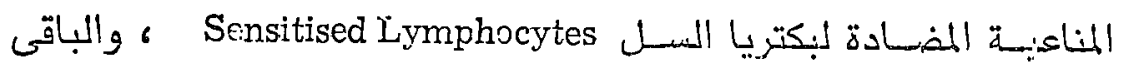
Macrophages

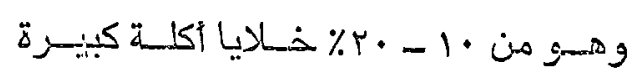

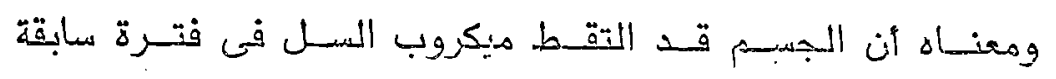

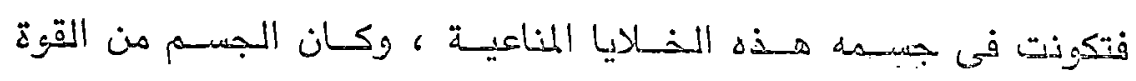

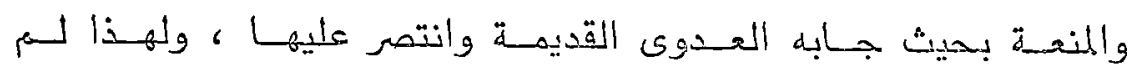

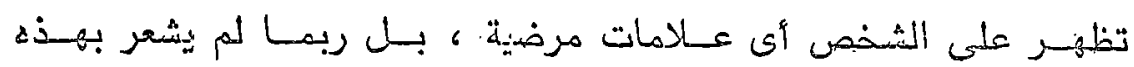
المواقوهـة لمعن

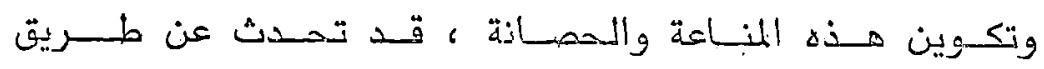

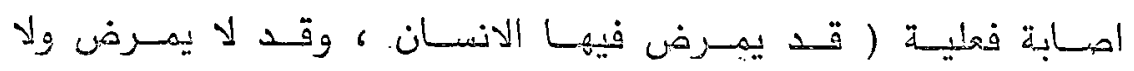

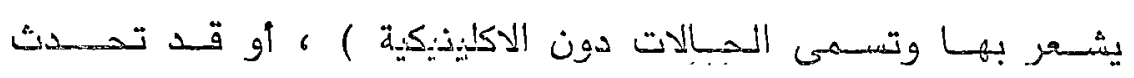

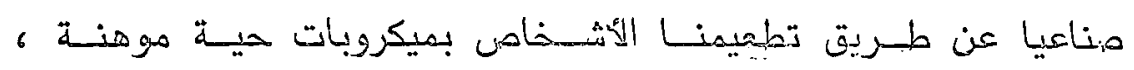

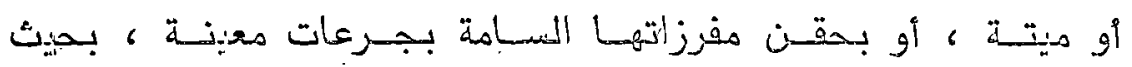

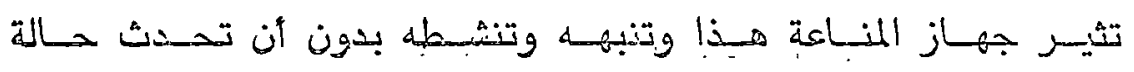
مرفهـية لهيت

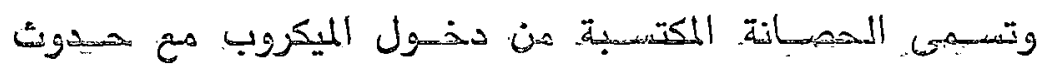

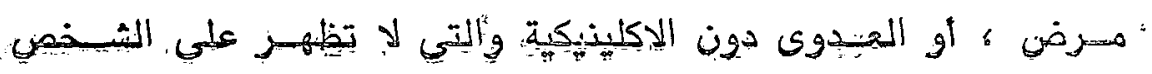


فيهـا أعـراض مرضـية ـ تشهى : بالمنـاعة النشـطة المكتسبة طبيعيا) Natural Aquired Active Immunity

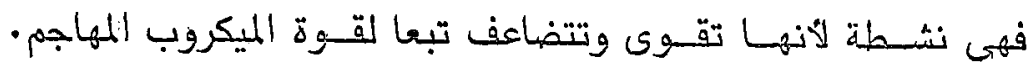

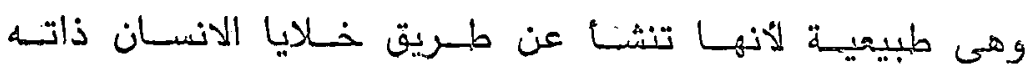

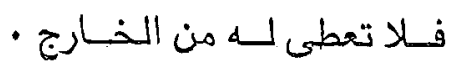

ومنــاعة التطعيسمن تسـهى بالمــاعة الصناعية : Artificial Active Aquired Immunity

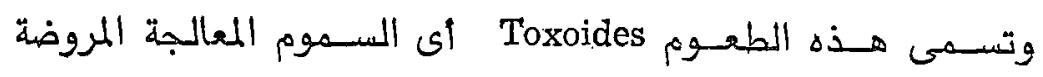

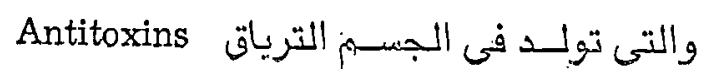

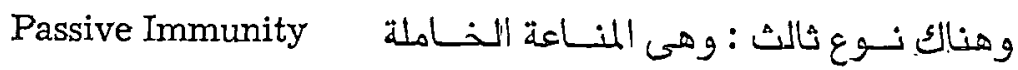

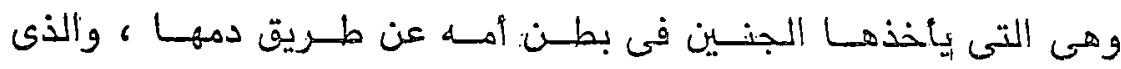

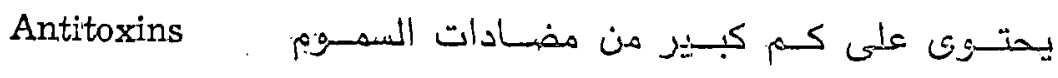

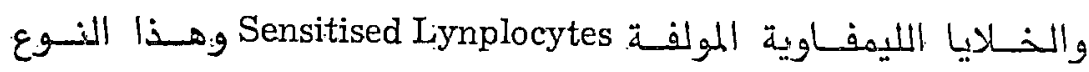

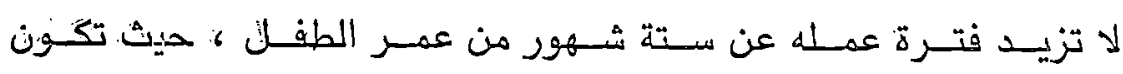

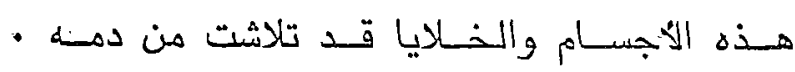

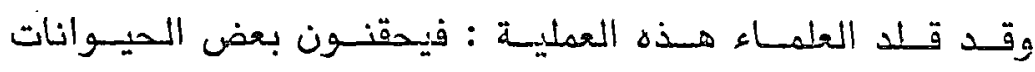

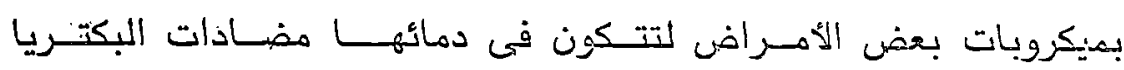

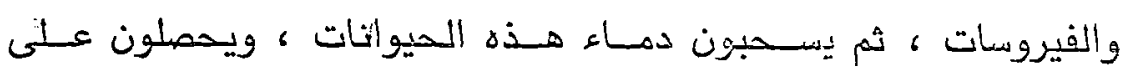

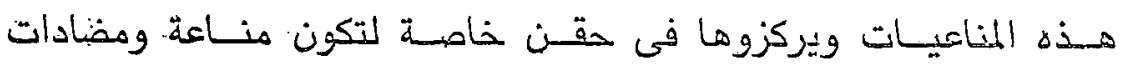

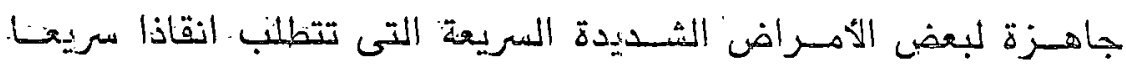

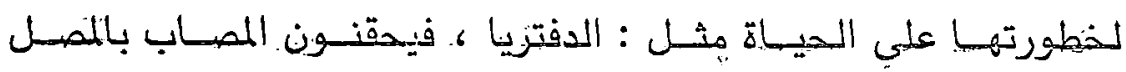
المواقى والمعالج Diphtheretic Antitoxin Serum لا يمكن في مثـلن هـده:

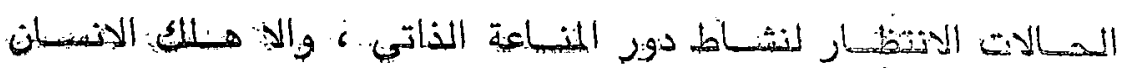




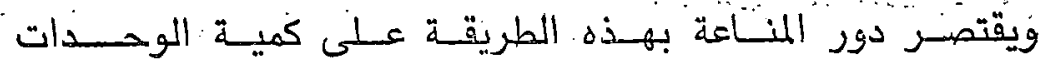

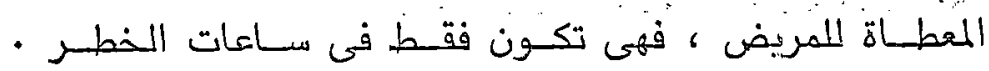

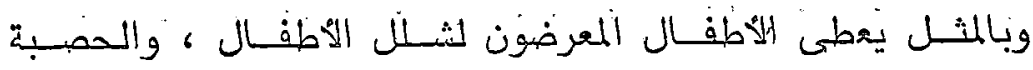

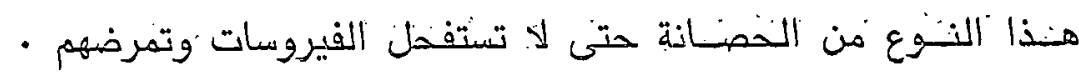

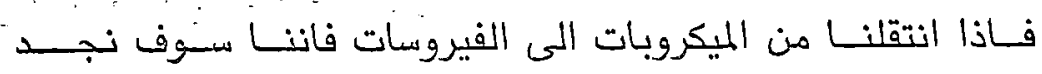

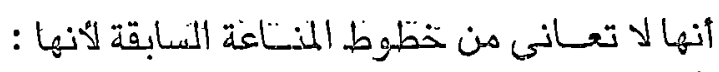

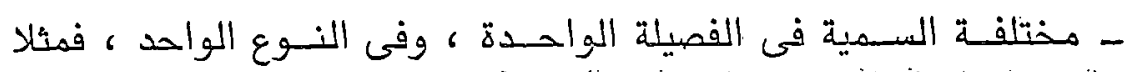

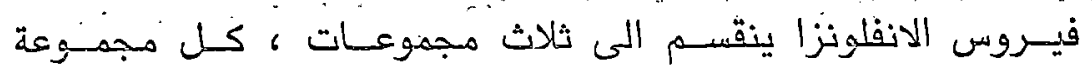

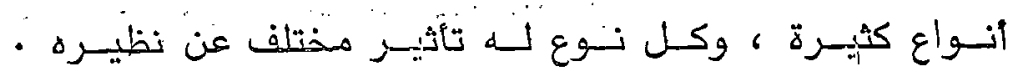

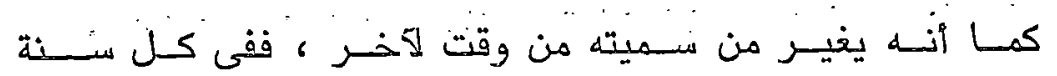

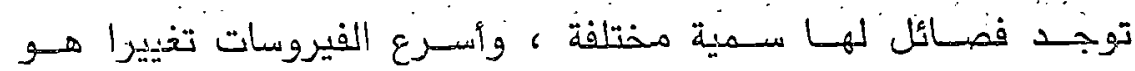

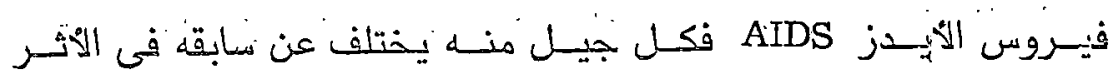

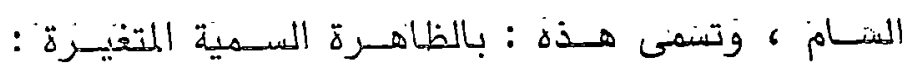
Common Cold

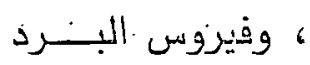
Antigenic Drift

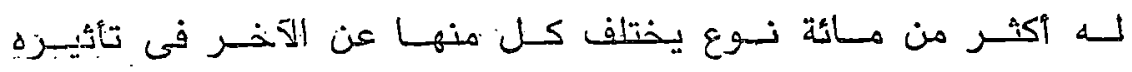

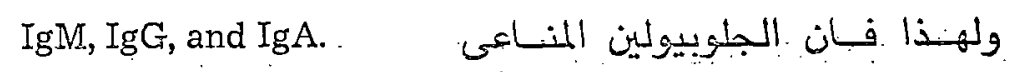

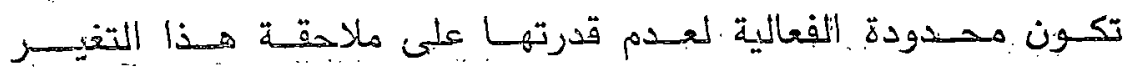

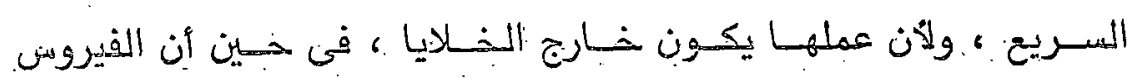

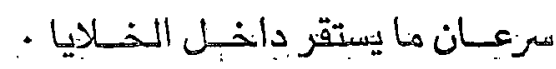

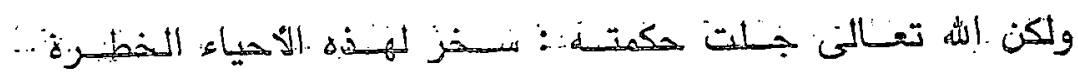

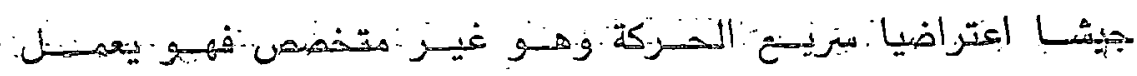

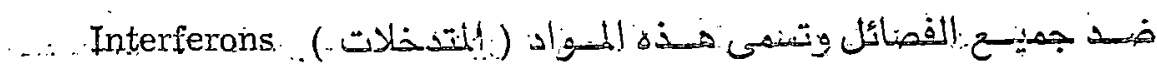

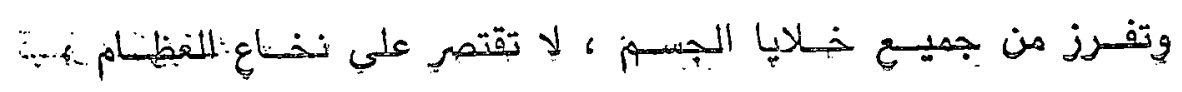




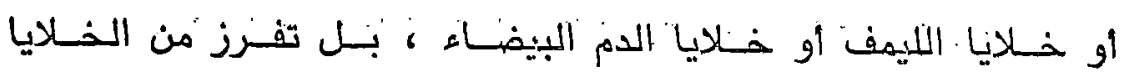

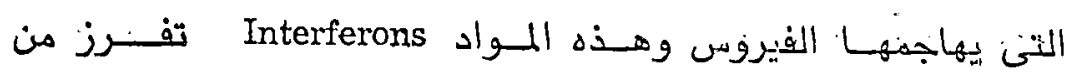

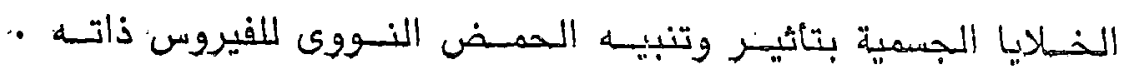

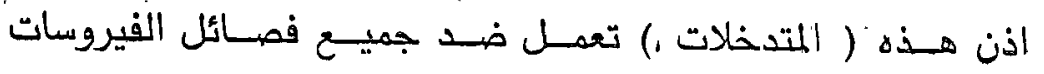

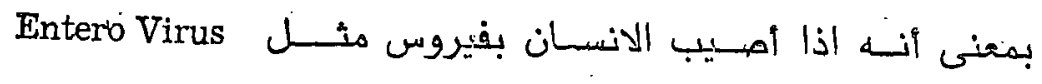

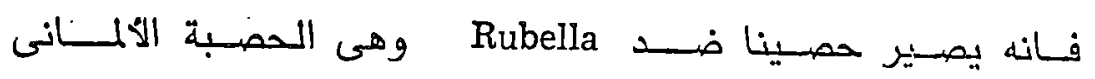

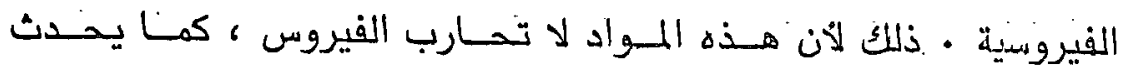

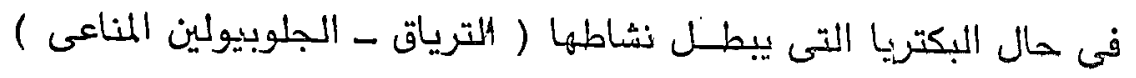

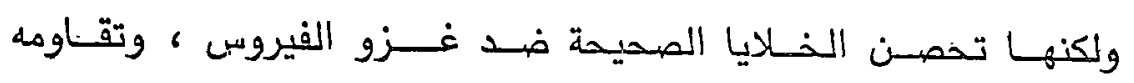

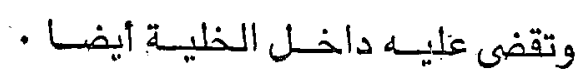

كيـا أنـه اذا كانت هـادة ( الترياق Antibodies ) تظبهـر

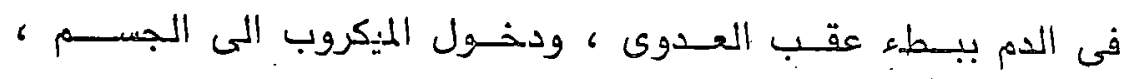

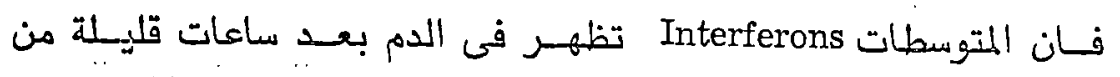

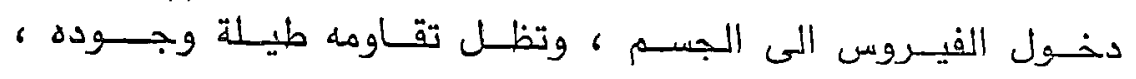

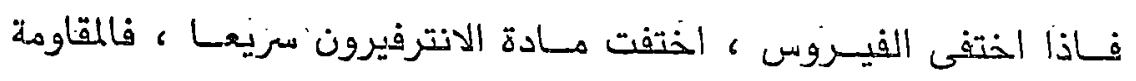

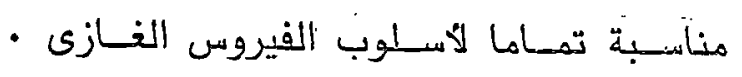
وهــكذا فقـد جعـل الله تعـالى لـكل خطــر ما يناسبه من وسـائل

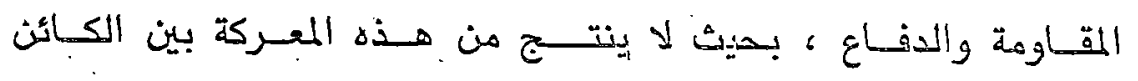

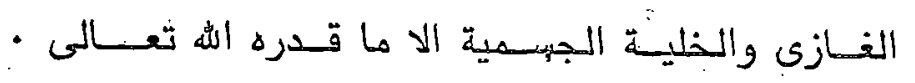

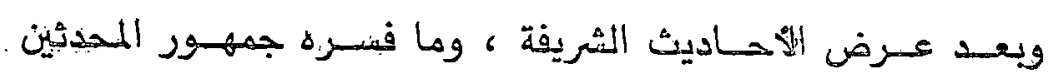

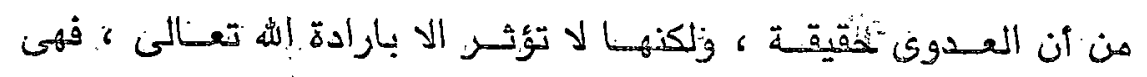

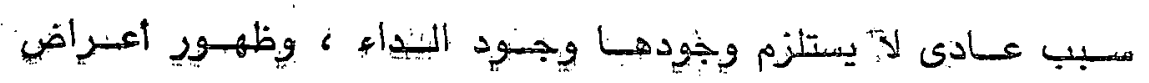




\section{- 证 -}

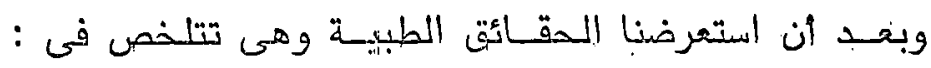

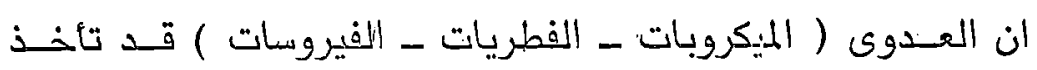

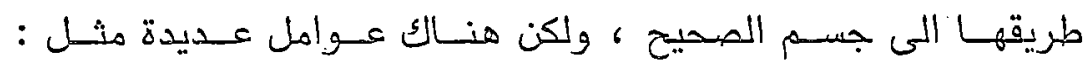

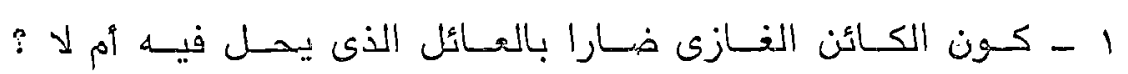

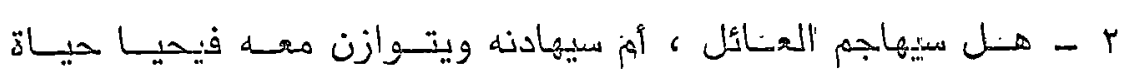
تعايشية تكافلية الفية

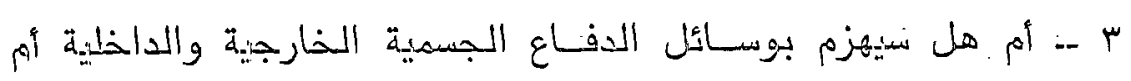
ينتصـر ويتظلب ويسـبب حسالة مرخسية .

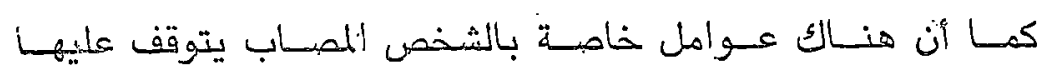

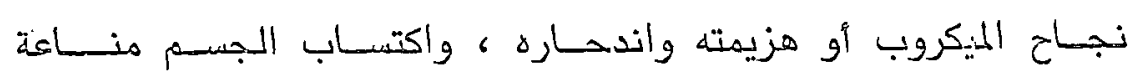

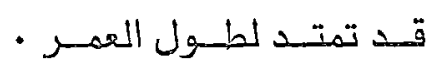
هن هـذة العهواهل

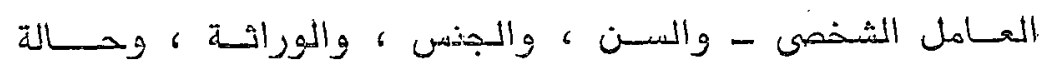

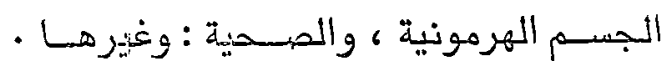

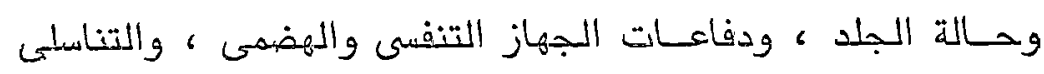

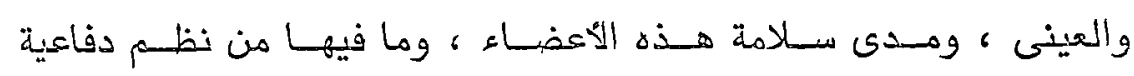

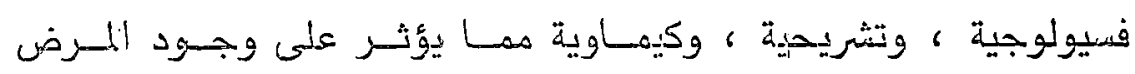
أو عـدمده

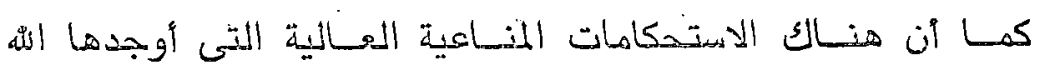

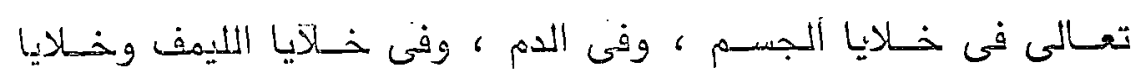

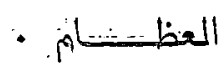

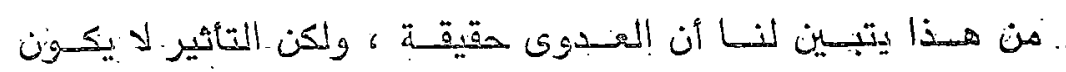

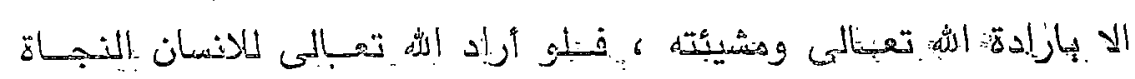

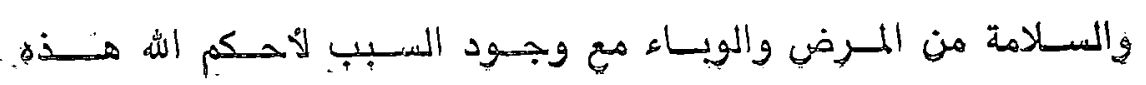




\section{$-w$}

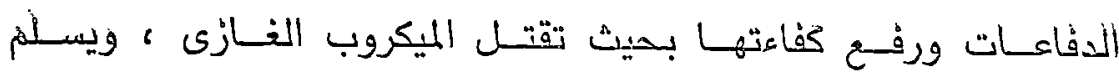

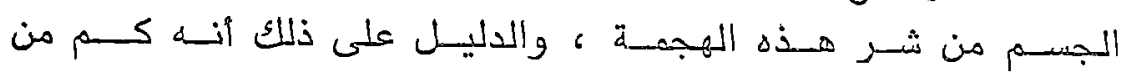

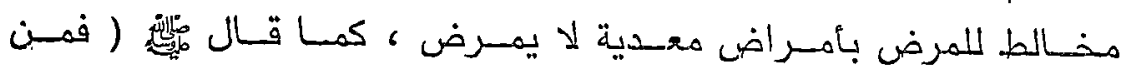
- أعهدى الإول

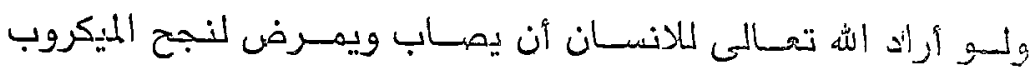

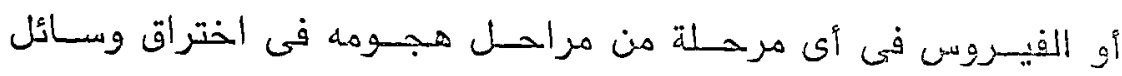

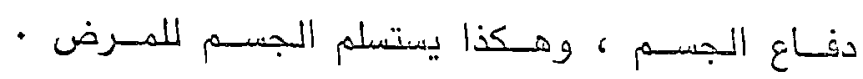

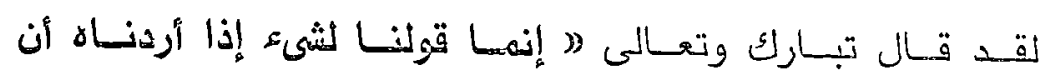

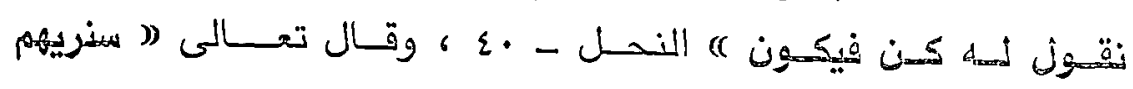

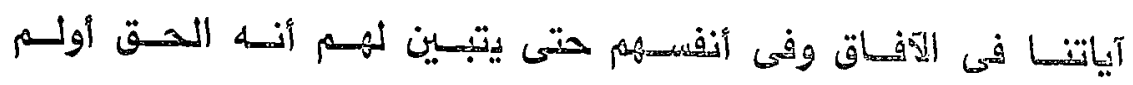

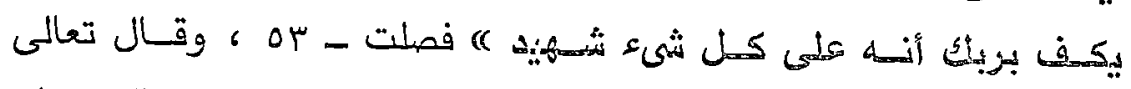

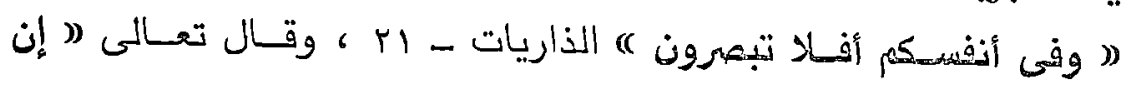

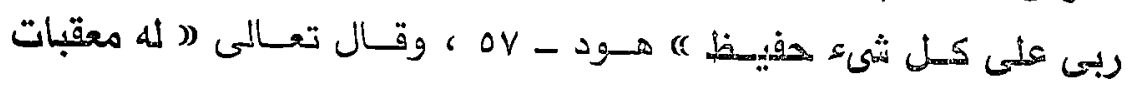

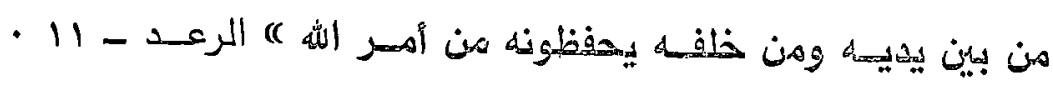

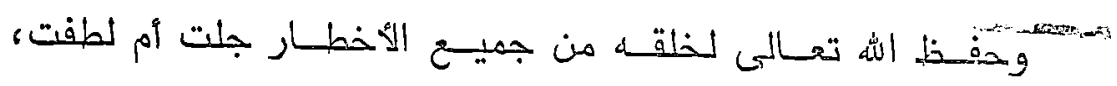

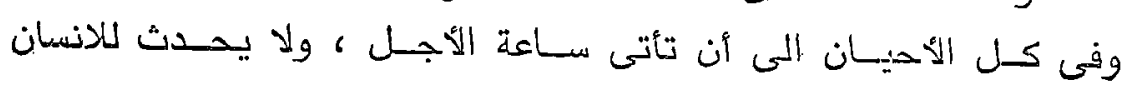

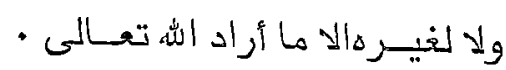

( قـال عكرمة عن ابن عبـاس ( يحفظونه من أمسر الله ، ) قـال

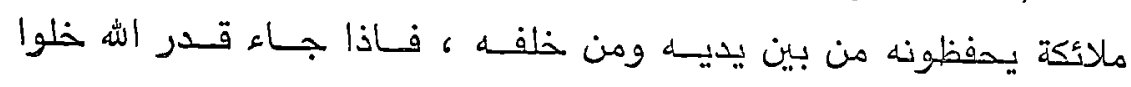

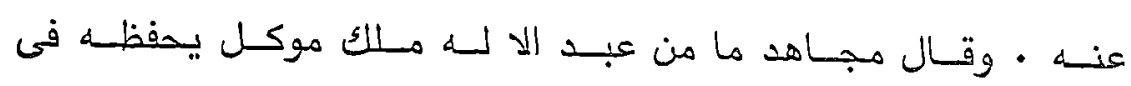

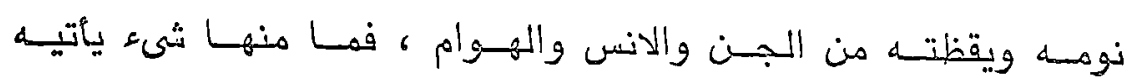

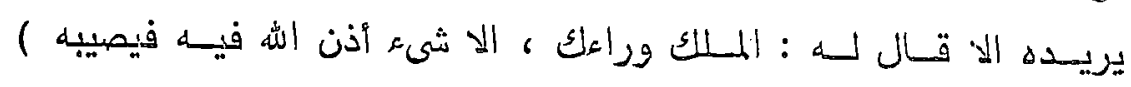

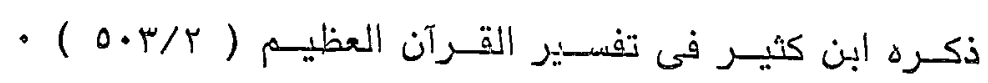

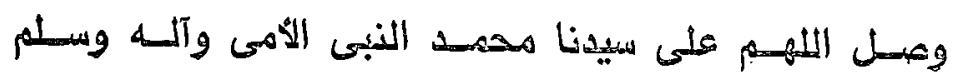

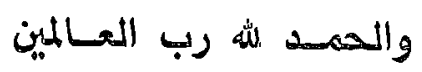


